\title{
Counter Hydro Hegemony Mechanisms and Their Roles in the Eastern Nile Basin
}

\author{
Gashaw Ayferam Endaylalu, \\ Lecturer at the Department of Civics and Ethical Studies, College of Social Science and Humanities, Debre \\ Brehan University
}

\begin{abstract}
This study examined ways of challenging hydro hegemony and their roles in the Eastern Nile Basin. In doing so, the study has employed a qualitative research approach and Framework of Counter Hydro Hegemony which gives due emphasis to power and hegemony in transboundary water analysis which is downplayed by the conventional analysis of the conflict-cooperation continuum. The study has used both primary and secondary sources of data in which primary data were gathered through key informant interviews. In this case, Face-to-face interviews were conducted with individuals from academic institutions, Stockholm international water institute, Ethiopian Ministry of Water, Energy and Irrigation, Ethiopian Ministry of Foreign Affairs, and Eastern Nile Technical Regional Office (ENTRO), and Electronic (e-mail) interviews were also conducted with international water experts. Secondary data also gathered form books, journal articles, archival sources, agreements, agreed minutes, speeches, reports, and other pertinent internet sources. Given the data are gathered qualitative, the study has employed qualitative data analysis is techniques in which a combination of discourse and document analysis has been used. The findings of the study show that in the contemporary hydropolitics of the Eastern Nile basin, Egypt's hydro hegemony is being challenged via two ways: war of position through CFA and war of movement through GERD. Both of them have played crucial roles not only in challenging but also in foreshadowing the end of the inequitable transboundary water management. With regard to CFA, it has envisioned a new order. In the meantime, however, CFA has no legal value because the ratification is not yet reached the minimum required number. Rather CFA has a counter hydro hegemonic role. CFA has the role of breaking of hegemonic consent and transformative. Along to this, CFA has a role in creating counter hydro hegemonic narrative: downgrading the narrative of historical and acquired rights via narrative of equitable and reasonable utilization, securitization via desecuritization, win-lose via win-win, and you can live without Nile via we need Nile for development. With regard to GERD, it has a coercive counter hydro hegemonic role. Along this the roles of GERD includes ways of exercising rights, coercive role, counter sanctioned discourse and offering of alternative discourse, showing the imperative of cooperation, and creation of benefit sharing regime. Thus, the counter hydro hegemonic strategies in the contemporary hydropolitics of the Eastern Nile basin foreshadow an emergent new equitable regime. Nevertheless, the anticipated new regime has not been realized. Rather it has faced challenges because of the proactive and reactive hydro hegemonic tactics being employed by Egypt.
\end{abstract}

Keywords: Counter Hydro Hegemony, Eastern Nile Basin, Ethiopia, Egypt, CFA, GERD

DOI: $10.7176 / \mathrm{IAGS} / 69-02$

\section{Introduction}

The Nile River is world's longest river which is the principal artery of life, the cradle of civilization, a bone of contention, a magnet for tourism, stimulus to expedition and exploration (Al Rasheedy and Hamdy, 2007: 26; Swain, 2011:688). Since antiquity Nile River basin has attracted the attention of explorers, expansionists, poets, philosophers, politicians, geographers, environmentalists, hydrologists and policy makers with competing interests (Bayeleyegn, 1998:361; Yohannes, 2008:1). Its greatness and numerous values for its inhabitants are quoted by Naden as " "no other river is so important to a people. And no other river is so rich in history. This is the mysterious river Nile _ the longest river system in the world_the river of romance"' (Naden, 1973:28 as quoted in Bayeleyegn, 1998:361). Nile River is one of the complex river basin in the world because of its large size with small discharges, diverse climatic zones and divergent interest of countries belongs to the river.

Hydro-geographically, Nile River flows $6,825 \mathrm{~km}$ over 35 degrees of latitude from south into northeast towards the Mediterranean Sea crossing highly diverse landscapes and climatic zones (Yacob, 2007:25; Nile Basin Initiative (NBI), 2016:15; Egypt country paper, 2000:38). The Nile basin covers an area of more than 3 million $\mathrm{km}^{2}$, nearly $10 \%$ of the land mass of African continent, in 11 countries that share the river: Burundi, Democratic republic of Congo, Egypt, Eritrea, Ethiopia, Kenya, Rwanda, Sudan, South Sudan, Tanzania and Uganda. The river is home to more than 257 million people nearly $54 \%$ of the total population of the 11 countries (NBI, 2016:15).

Hydrologically, the Nile River has several tributaries and headwater lakes which can be classified into two broad subsystems: the Eastern Nile subsystem and the Equatorial subsystem. The Eastern Nile subsystem comprises four sub basins, the main Nile starting from the White-Blue Nile confluence at Khartoum, the Abbay, Baro-Akobo-Sobat, and the Tekeze-Atbara (NBI, 2016:35-39; Yacob, 2000:610). The Equatorial Nile subsystem 
embraces the equatorial lakes which are generally referred as the White Nile which all together contributes $14 \%$ of the total flow of the Nile River (NBI, 2016:39-45).

The Eastern Nile basin covers approximately 2,695, 300 $\mathrm{km}^{2}$ of which the main Nile covers $44 \%$ and the Abbay, Baro-Akobo-Sobat and the Tekeze-Atbara altogether covers the remaining percentage (Eastern Nile Technical Regional Office (ENTRO), 2016). The source of Abbay River is the spring of Gish Abbay in Sekela, Gojjam, which flows as Gilgel Abbay into the wide and shallow Lake Tana which receives other tributaries including Megech, Ribb and Gumara (Oestigaard and Gedef, 2011:27).

On the left bank of the river, the tributaries are Beshilo, Welaka, Jema, Muger, Guder, Fincha, Dabus and Didessa and the right bank tributaries are small streams from Gojjam highlands, Abeya, Suha, Chemoga, Birr, Fettam, Dura, and Beles and other tributaries such as Rahad and Dinder joins in downstream Sudan (Federal Democratic Republic of Ethiopia (FDRE), 1998a:11; ENTRO; 2016; Bureau of Reclamation, 1964:2; Yacob, 2000:611). The Baro-Akobo-Sobat river basin originates from Ethiopian plateaus and then flows into South Sudan in the West. Major rivers within this sub-basin are Baro with its tributaries Birbir, Geba, Sore; Alwero, Gileo with its tributaries Gecheb, Bitun and Beg; Akobo with its tributaries Kashu (FDRE, 1997:2; Yacob, 2000:611; ENTRO, 2016). Pibor River which flows from southern Sudan and northern Uganda is also tributary of this sub-Basin (ENTOR, 2016). Finally, the Tekeze-Atbara river flows from its source as spring near Lalibela into Sudan. Tributaries of this sub-basin are the Angereb and Goage and other small streams are Zamra, Tserare, Geba, Wori, Zarema and Insia (FDRE, 1998b:3.1.).

The Eastern Nile basin is characterized by a number of asymmetries which ranges from water endowment and use to exploiting potential and power relation (Cascão, 2009: 248; Alan, 2009:749). The interest of Eastern Nile basin countries and their position on the basin key issue, equitable entitlement and regional cooperation, and their contribution to and use of the Nile waters are also differ considerably. In this regard, a bulk of academic hydropolitical research highly associate the Nile River in particular the Eastern Nile basin with the 'water war' and 'water peace' narratives. However, neither overt conflict nor principled cooperation is actually realized. This led scholars to theorize power and hegemony, on the basin of Gramsci notion of hegemony and Stevin Lukes three faces of power, in transboundary water resources studies ${ }^{1}$. Viewing hydropolitics as allocative politics of 'who gets how much of water, how and why', hydro hegemony scholars assert that "control over water resources is not achieved through water wars but through a suite of power-related tactics and strategies such as resource capture, integration and containment" (Warner and Mark, 2006:436).

The concept of Hydro hegemony is adopted from Antonio Gramsci notion of hegemony. In their original framework paper, Warner and Mark (2006:435) defined hydro hegemony as hegemony at basin level attained and maintained "through water resource control strategies such as resource capture, integration and containment" that are executed through several tactics_coercion, utilitarian, normative and ideological hegemonic compliance mechanism (knowledge construction, securitization and sanctioned discourse) that are enabled by existing power asymmetry and exploiting potential of the riparian. In the Framework of Hydro Hegemony, power along with exploiting potential is regarded as the determining factor in controlling water resources. Warner and Mark (2006: 442), based up on Lukes (1974) categorization of power, identifies three pillars of power: material (military, economic power, expert power and technological advancement), ideational (power through, over and in ideas) and bargaining power (power of persuasion). However, in the revised pillars of hydro-hegemony, Cascão and Zeitoun (2010:32) added geography (riparian position-upstream or downstream) as a fourth pillar of power.

Hegemonic transboundary water arrangement is thus established "on the four fields of both covert and overt forms of power" (Cascão and Zeitoun 2010:32). Thus, hydro hegemonic power is 'the first amongst equals' or the more powerful riparian of formally equal parties that has established ways of controlling the water resources through smart power, a combination of hard and soft power (Warner and Mark, 2008:805). The concept of Hydro-hegemony is thus employed in transboundary water resources studies to make a distinction of those water arrangement systems based on principle of equitable distribution of shared water resources among riparians from that of hegemonic transboundary water arrangement system whereby the powerful riparian or "the first among equals' control the river basin shared water resource (Wessels, 2015:602-603). This is particularly true over five transboundary River basins: Egypt on the Nile, Turkey on Tigris-Euphrates (Warner and Neda, 2012 Para. 14), China on the Mekong (Rein, 2014:130; Warner and Neda, 2012 Para. 14), India on the Ganges (Warner and Neda, 2012 Para. 14) and Israel on Jordan (Zeitoun, 2008:145-153). According to Warner and Mark (2006:435 and 455), hydro-hegemons over Nile, Jordan, and Tigris-Euphrates resulted extremely inequitable utilization of the shared Rivers. Because of the existence of hydro hegemony, Egypt, complete transformation of the Nile river basin from monopolization, competition and unilateralism into cooperation and shared utilization remains an ideal scenario.

\footnotetext{
${ }^{1}$ Warner, Jeroen and Mark Zeitoun (2006). Hydro-hegemony - a framework for analysis of trans-boundary water conflicts. Water Policy 8 , Pp. 435-460.
} 
Nevertheless, hydro hegemonic transboundary water arrangement system is not a static reality. Rather it can be challenged and transformed. In this regard, Cascão (2008) develops, based up on the work of Zeitoun and Warner, a 'framework of counter-hydro hegemony'. When a hydro hegemony creates inflexible, inequitable, and unsustainable outcomes, non-hegemonic riparians can use various strategies and tactics to transform the rule of the game. However, countering historically rooted basin hydro hegemony and working towards a more equitable order is not an easy task. Cascão (2007) (as quoted in Zeitoun, 2008:1) argued that "“counter-hegemonic strategies are considerably broader than revolution and independence movement"”.

According to Cascão's framework of counter hydro hegemony, strategies to be used by non-hegemonic riparians include contesting the legitimacy of the order, envisioning alternatives, and challenging the status quo. The tactics to be used are coercive, leverage, and liberating mechanisms (Cascão et al., 2016:4; Kistin, 2010:8486). The tactics of leverage mechanisms are water diplomacy, unilateral construction of infrastructure, coalition with other non-hegemonic riparians and formation of basin-wide institutions and agreements. With regard to the Nile River basin, non-hegemonic riparians has been challenging the age-old Egypt's hydro-hegemony (Abadir, 2011:284; Cascão, 2009:249; Warner and Neda, 2012, para. 18). Thus, different rhetoric and real counter hydrohegemony mechanisms have been used such as Nile Basin Initiative (NBI), Comprehensive Framework Agreement (CFA) (Abadir, 2011:284) and a unilateral construction of infrastructure. Nevertheless, an equity treaty based regime is still under ideal scenario.

In the contemporary literature of the hydropolitics of Nile, however, some scholars tended to label CFA and GERD as 'the beginning of the end of Egyptian hydro political hegemony' (Abadir, 2011) and 'ending Africa's oldest geopolitical rivalry' (Goitom, 2014) respectively. However, viewing the recent developments in the hydropolitics of Nile as a change in Egypt's policy and the end of hegemony would be naïve. It seems a paradox and colour change. Egypt has continued to maintain the status quo by using various hydro hegemonic compliance producing mechanisms _ found cost-effective. History shows that Egypt would use everything either of hard or soft power or both of them_depends on the situation to preserve its hydro hegemonic position. At this moment, it is necessary to remember the word of Werner Munzinger "Ethiopia... is a danger for Egypt. Egypt must either take over Ethiopia and Islamize it, or retain it in anarchy and misery"' (as quoted in Daniel, 1999:145). Now after a century Egypt has been turned to the second alternatives_destabilizing Ethiopia and the region_and at the same time Egypt is using soft power to win the heart of the riparians. Thus, hydro hegemonic compliance mechanisms and counter hydro hegemonic strategies can co-exist.

In this regard, it seems worthwhile to employ a holistic approach, a combination of 'hydro hegemony and counter hydro hegemony framework', to examine the roles and challenges of counter hegemonic strategies and tactics in creating a new order based up on the principle of equitability and sustainability. The intention of this research is, therefore, to examine the roles and challenges counter hydro hegemonic strategies in countering hydro-hegemony and in turn in inducing a more equitable new order. The strategies and tactics employed by the hydro-hegemon, Egypt, in shielding and prolonging the lifespan of the status quo are also part of the study.

\section{Research Methods}

Methodologically, the study employed qualitative research methodology. In view of that, the study used both primary and secondary source of data. The primary source of data was collected through key informant interviews while the secondary data was collected from books, published journal articles, published and unpublished theses and dissertation, governmental and non-governmental organization reports and remarks, speeches, magazines and other internet sources. Given the data gathered are qualitative; the study employed qualitative data analysis techniques of which historical narrative, document and critical discourse analysis has been used.

In view of that, the paper contains two sections. The first section gives a brief description and analysis of how and when Egypt's hydro hegemonic position and the current hydropolitical status quo of Nile River in particular the Eastern Nile basin is being established, maintained and consolidated. In doing so, a historical perspective along with theory of hydro hegemony was employed. The second section analyses the changing power relation in the Eastern Nile basin with due emphasis to the underlying factors for such changes and their implication in eroding the hydropolitical status quo of the Eastern Nile basin.

\section{Twin Ways of Challenging Egypt's Incessant Hydro Hegemony}

Before scrutinising the roles of counter hydro hegemony mechanisms in eroding hydro hegemonic transboundary water arrangement and thereby creating a new transformative order, it seems worthwhile to identify ways that countries sharing transboundary water resources contest hydro hegemonic water arrangements. In this case, nonhegemonic riparians can put hegemonic created 'transboundary water arrangement', hegemonic order, at risk through two ways: war of position through multilateral forums and war of movement through national resource capture strategy.

The first crucial mechanism is multilateral move against the hegemonic order with or without the 
hegemonic power in the latter case it can be called 'non-hegemonic alliance'. As defined earlier hydro hegemonic power is 'the first amongst equals' or the more powerful in terms of the Steven Lukes three dimension of power. The implication is that collective bargaining power employed by non-hegemonic riparians is more consequential ${ }^{1}$. The formation of multilateral institutions at river basin level has thus paramount importance in transforming the inequitable order being canonized by the basin powerful riparian most often the hydro hegemon towards a new order based on principles of international water law.

Keohane (1990: 731) defined multilateralism as "the practice of coordinating national policies in groups of three or more states, through ad hoc arrangements or by means of institutions". Multilateral institutions can serves as a forum for the exchange of information and it also enhance bargaining power to exploit potential opportunities (Keohane, 1990). Multilateral forums are thus important in pursuing the strategy of 'war of position', which is a slow process of undermining the 'common sense' base of the hegemonic power and in so doing it creates and strengthen the social foundation of the new order (Cox,1993:165). By using their collective bargaining power and resources the non-hegemonic riparians would bring a complete transformation from inequitable hegemonic created order into a new equity based regime. This is, however, executed through the use of several tactics most often a combination of hard and soft power related mechanisms. In asymmetrical transboundary water arrangement like the Nile River non-hegemonic powers collective bargaining power has paramount importance in influencing and persuading hegemonic power as well as external actors about the unfairness of existing status quo and the imperative of a new order.

The post 1990's Nile history shows the bitter struggle of upstream countries in quest for a new order. The establishment of Nile Basin Initiative in 1999 which serves as a forum of discussion about the viable mechanism of cooperation in the basin (NBI Act, 2002) has played a crucial role in enabling upstream countries in translating their occasional based unilateral verbal contestation of the existing status quo into actual contestation and unified negotiation position. With the establishment of NBI, upstream countries also become more active with a shift from challenger of the status quo to actual changer. The post 1990's multilateral negotiation on the Nile River is thus levelled as 'a battle of hegemonic power and non-hegemonic riparians'. The basin hydro hegemon, Egypt, has used hegemonic bit throughout the decade of Nile negotiation so as to prolong the lifespan of the status quo. In contrast, non-hegemonic riparians have successfully exploited their bargaining power to ended-up the hydropolitical status quo established by the 1929 and 1959 agreements (Tawfik, 2016:68). Such negotiations finally bring a fresh legal framework, cooperative Framework of Agreement (CFA), and nonhegemonic alliance. Thus, one mechanism through which hegemonic order is contested and challenged is through multilateral forums.

The second mechanism is unilateral way of contesting the established state of affairs. This can be levelled as 'creating facts on the ground'. This includes the decision of non-hegemonic riparian to develop their water resources without the request of hegemonic blessing. In this case, a resource capture strategy (the development of multipurpose hydraulic infrastructure such as hydro power plant and large-scale irrigation schemes) by nonhegemonic riparians is the most consequential ways of counter hydro hegemony. In the Nile river basin, upstream riparians unilateral moves and 'hydraulic missions' has an implication to the hydropolitical status quo of Nile. Of these Grand Ethiopian Renaissance Dam (GERD) is more consequential. In general, there are two ways through which inequitable hegemonic order can be transformed. The first mechanism is normative instrument while the other is resource capture strategy and both of them are discussed and analysed separately in the following section.

\subsection{The Nile River Basin Cooperative Framework Agreement: A Move Towards the Creation of Upstream Counter Hydro Hegemony Narrative}

3.1.1. The Evolution of Nile River Basin Cooperative Framework of Agreement

Pre-NBI cooperative efforts for the Nile river basin institutional frameworks has successfully failed just because of the non-inclusiveness and hegemonic partiality of the cooperative platform and the non-negotiable position of downstream countries on legal issues (Tesfaye, 2001:1; Cascão, 2012:231; Yacob, 2007:213). All previous cooperative efforts were initiated by Egypt and their priority area of cooperation was technical and thus legal issues were intentionally ignored. However, with the changing environment (domestic, regional and international) of the post 1990's period non-hegemonic riparians notably Ethiopia has challenged the hegemonic status quo.

Subsequently, a new all-inclusive multilateral cooperation process is initiated with a dual track approach: technical and legal approach ${ }^{2}$. The first track is the technical cooperation with the NBI, a transitional intergovernmental institution established on 22 February 1999 with an overarching vision of "achieving sustainable socio-economic development through equitable utilization of, and benefit from, the common Nile

\footnotetext{
${ }^{1}$ Interview with Ana Elisa Cascão (PhD), Programme Manager of Transboundary Water Management, Stockholm International Water Institute, March 2017

${ }^{2}$ Interview with Ana Elisa Cascão (PhD), Supra Note 2 Interview with Fekahmed Negash, Executive Director of ENTRO, April 2017, Addis Ababa, Ethiopia;
} 
Basin water resources"1. And the second track constitutes multilateral negotiations for a comprehensive legal framework: Cooperative Framework of Agreement (hereafter CFA).

The framework of agreement was initially known as the D3 project, one of the twenty two identified projects by Nile river basin action plan (hereafter $\mathrm{NRBAP}^{2}$ ). The D3 project was unanimously adopted by all participants of Nile riparians at the third ministerial meeting at Arusha, Tanzania, February 1995. The short term objective of the D3 project was to develop a comprehensive framework of agreement acceptable for all countries $^{3}$. It's long term objective was " to pave the way for the Nile river basin countries to achieve milestones which would determine net equitable entitlements for each riparian country for the use of the Nile waters and therefore to enhance and promote the utilization of the Nile waters for optimum sustainable socio-economic benefits for the inhabitants of the basin ${ }^{4}$ ". The subsequent adoption of CFA by Nile riparians would promote and result for the establishment of a permanent institutional framework, Nile river basin commission which will replace the transitional $\mathrm{NBI}^{5}$.

Upon the adoption of the D-3 project by the Nile-COM, the United Nations Development Program (hereafter UNDP) came to the forefront as funder of the project. In accordance with the term of reference on the work of the panel of experts as approved by the water resources ministers at Arusha, the Panel of Experts (hereafter PoE) composed of three experts from each countries with the exception of Eritrea was established in $1996^{6}$. Then after the PoE started the negotiation for CFA as of January $1997^{7}$. For the purpose of drawing lesson and best practice for the Nile river basin, the PoE undertake a study tour to the Mekong River, Gambia River and Senegal River ${ }^{8}$. The PoE negotiated all provisions of the drafted document and finally came up with a revised version of CFA with a footnote explaining reservation (Tesfaye, 2011:268). Finally, the PoE has submitted the revised version of CFA along with reservation footnotes to the Nile-Com. The Nile-COM has discussed the revised draft of CFA at the Khartoum Nile-COM meeting in August 2000.

\footnotetext{
${ }^{1}$ The Nile Basin Initiative act, 2002, Available in Minutes of the 14th Nile Technical Advisory Committee (Nile-TAC), 16-18 December 2002.

${ }^{2}$ The Nile river basin action plan is a program approved by the council ministers for water affairs of the Nile Basin states participated at third ministerial meeting at Arusha, Tanzania, 1995. NRBAP aimed at promoting a comprehensive cooperative framework for water management in the Nile river basin. For this, the action plan identifies twenty two projects under five headings. The D3 project was among the five projects identified under project D (regional Cooperation). For more see TECCONILE. The Nile River Basin Action Plan (1995).

${ }^{3}$ TECCONILE. The Nile River Basin Action Plan (1995).

${ }^{4}$ Panel of Experts (1999). Nile river basin cooperative framework Project (D-3) Final Report [Draft Report 1.7-Decmber 1999].

Agreement on the Nile River Basin Cooperative Framework. Article 30, Retrieved September 2016 from http://www.gcao.gov.et/documents/10184/19296/L10-The+Nile+BasinAgreemen.pdf/7a063de9-9e08-4585-9a32-c3bfaf1a9490?version=1.0 ${ }^{6}$ Panel of Experts, Supra Note 7

${ }^{7}$ NBI, Cooperative Framework Agreement. Retrieved 20 February, 2017 from thttp://www.nilebasin.org/index.php/nbi/cooperativeframework-agreement

${ }^{8}$ Panel of Experts, Supra Note 7, Pp. 75-85
} 
Table 1.1: Evolution of the Cooperative Framework Agreement

\begin{tabular}{lll}
\hline Dates & Stage & Brief Description \\
\hline Jan 1997- Mar 2000 & Panel of Experts & $\begin{array}{l}\text { Text, or working document of principles, rights and } \\
\text { obligations, and institutions, prepared. }\end{array}$ \\
\hline Aug 2000- Aug 2001 & Transitional Committee & Text converted into draft Agreement. \\
\hline Dec 2003- Dec 2005 & $\begin{array}{l}\text { Negotiations } \\
\text { Committee }\end{array}$ & $\begin{array}{l}\text { Draft Agreement negotiated with full } \\
\text { mandate. Numerous reservations ('brackets' - }\end{array}$
\end{tabular}

$\begin{array}{ll}\text { Mar } 2006 \text { - Jun } 2007 & \text { Ministerial } \\ & \text { Negotiations }\end{array}$
alternative texts representing different positions) remain.

\begin{tabular}{lll}
\hline August 2008 & Nile-COM & $\begin{array}{l}\text { Feengagement, re-opening of the file at the } \\
\text { Ministerial level. }\end{array}$ \\
\hline Kinshasa Meeting May 22, Nile-COM & 7 member countries agree to annex Article 14b for
\end{tabular}
2009 7 member countries agree to annex Article 14b for later resolution by NRBC; reservation by Egypt; Sudan not present at time of decision, but subsequently expressed its reservation.

\begin{tabular}{|c|c|c|}
\hline Nairobi July 3, 2009 & $\begin{array}{l}\text { Meeting of country } \\
\text { negotiators }\end{array}$ & $\begin{array}{l}7 \text { countries agree on a cleaned text; strong } \\
\text { reservations by Egypt and Sudan }\end{array}$ \\
\hline $\begin{array}{lll}\text { Alexandria } & \text { Meeting } & \text { July } \\
27 / 28,2009 & & \end{array}$ & Nile-COM & $\begin{array}{l}\text { Joint decision to allow for more time to seek joint } \\
\text { agreement }\end{array}$ \\
\hline $\begin{array}{l}\text { Entebbe, Sept } 2009 \\
\text { Dar es Salaam, Dec } 2009 \\
\text { Sharm el Sheikh, Apr } 2010\end{array}$ & $\begin{array}{l}\text { Joint Nile-TAC and } \\
\text { Negotiators Committee }\end{array}$ & Deliberations on options to move forward together \\
\hline $\begin{array}{l}\text { Sharm el Sheikh Meeting } \\
\text { April 13, 2010 }\end{array}$ & Nile-COM & $\begin{array}{l}7 \text { countries agree to open CFA (cleaned text) for } \\
\text { signature; position rejected by Egypt and Sudan }\end{array}$ \\
\hline May 14, 2010 & $\begin{array}{l}\text { CFA opened } \\
\text { signature }\end{array}$ & $\begin{array}{l}4 \text { countries (Ethiopia, Rwanda, Tanzania, and } \\
\text { Uganda) sign the opened CFA in Entebbe, Uganda }\end{array}$ \\
\hline May 19, 2010 & & Kenya signs the CFA in Nairobi, Kenya \\
\hline February 28, 2011 & & Burundi signs the CFA in Bujumbura, Burundi \\
\hline June 13, 2013 & Ratification & Ethiopia ratifies the CFA \\
\hline August 28, 2013 & Ratification & Rwanda ratifies the CFA \\
\hline March 26, 2015 & Ratification & Tanzania ratifies the CFA \\
\hline
\end{tabular}

Sadly, the revised cooperative framework document was not fully accepted by the Nile-COM and even at worst additional clauses were incorporated into CFA. At the aforementioned ministerial meeting, Nile-COM realize that "substantive issues in the cooperative framework remain unresolved" and to solve the stalemate the Nile-COM decided to established a Transitional Committee tasked with preparing the cooperative framework document in a proper manner and to be considered by the next negotiation committee (Kasimbazi, 2011:750a).

Although it is pointed out that the exclaimed 'unresolved issue' in the decade of CFA negotiations is use of terms such as 'Nile river system Vs. Nile river basin, equitable and reasonable utilization Vs. not to cause significant harm', and prior notification of planned projects, the real contentious issue is the egoistic intent of downstream riparians to shield the status quo created by the 1929 and 1959 agreements. Being aware of the end of the win-lose situation at the battle of negotiation, the downstream countries worked hard to canonize the status quo through CFA if not possible to make CFA structurally anaemic through intromission of technical terms aimed at buying of time ${ }^{1}$. In this regard, Egypt has used several hegemonic compliance producing mechanism of which securitisation and delaying mechanisms are successfully employed ${ }^{2}$.

With regard to the 'water security' there was extensive unfruitful discussion. The upstream countries want the clause in Article 14b "not to cause significant harm to the water security of any other Nile basin state" and in contrast the downstream countries want the replacement of the clause by "not to adversely affect the water security of current users and the rights of any other Nile basin country". The issue has become contentious and in the fifth meeting of Nile-COM in Kinshasha on 22 May 2009, water ministers of upstream countries have decided that CFA is a clear text ready for signature while the unsolved issue of article 14(b) would be annexed and the would be river commission will resolve it within six months of its establishment ${ }^{3}$. Since then, several

\footnotetext{
${ }^{1}$ Interview with Wuhibegezer Ferede, Assistant Professor at Bahirdar University, 19 February 2017.

${ }^{2}$ Interview with Dereje Zeleke (PhD), Assistant Professor of Law at Addis Ababa University, Ethiopia

${ }^{3}$ Agreement on the Nile River Basin Cooperative Framework. Article 30, Retrieved September 2016 from
} 
unfruitful meetings were held in different countries as in Kinshasa, DRC, in 22 May 2009; in Alexandria, Egypt from July 27-29, 2009; in Dar es Salaam, Tanzania, from December 10-11, 2009, in Nairobi, 3 July 2009, and in Sharm-el-Sheikh, Egypt, from April 132010 (Tesfaye, 2011:269; Kasimbazi, 2011:752-755a)

A new development was took place at the Nile-COM meeting in Sharm El-Sheikh, Egypt on 13 April 2010 where the upstream riparians decided to open CFA for signature. Since then, as stated in table 4.1, six countries have signed CFA and three of them have ratified.

\subsubsection{Hurdles in the Decade of CFA Negotiation and Egypt Current Position}

\subsubsection{Existing Treaty Regime}

Despite the phantom existence nature of the existing agreements, it has become a point of negotiation because of the ability of hegemonic power in making agenda 'on' and 'off'. The reason for the delayed negotiation of CFA and even current deadlock revolves around the issue of existing agreements. Throughout the negotiation period Egypt and Sudan egoistically defended the inequitable status quo. The provision that deals with the fate of the existing agreement is article 14 which is now replaced by a more ambiguous term 'water security' which is supposed to be a viable solution to break the deadlock. Sadly, it has never solved the problem rather a new challenge is witnessed, securitization. With the exception of downstream countries, all countries agreed on the provision of "existing agreements which are inconsistent with the framework shall be null and void to the extent of their inconsistency". Egypt and Sudan have a reservation to this clause and proposed that "the cooperative framework shall be without prejudice to existing agreements' ${ }^{1}$. Their position is also reaffirmed in the negotiation committee ${ }^{2}$. Ethiopia along with upstream countries has consistently declared the invalidity of the existing agreements. As a result, no progress was witnessed. As way out of the deadlock, an ambiguous concept 'water security' was introduced. However, Egypt has again used water security as an instrument of securitization and thereby prolonging the lifespan of the status quo. In an interview with Mona Sewilam, former minister of water resources and irrigation of Egypt (1997-2009) Dr. Mahmoud Abu- Zeid said that:

Egypt wanted to have a reference in the agreement to its water use, to the 55.5 billion cubic metres, because we [Egypt] discovered that it was very hard to include the historical agreements in the CFA. So we came up with the water security concept as a compromise from Egypt and Sudan...putting in an article on water security that refers to Egypt's and Sudan's water use ${ }^{3}$.

Egypt position on the existing agreement is still unchanged. According to Mahmoud Abu- Zeid, Egypt and Sudan are saying that they are currently using 55.5 and 18.5 BCM per year respectively and the remains 10 BCM is lost due to evaporation". The solution he forwarded is that "release of more water than the $84 \mathrm{BCM}$ per year as measured at Aswan Dam through cooperation and the use of science"5. Through cooperation aimed at saving of more waters from the White and Blue Nile he asserts that "Egypt and Sudan will continue to get what they are calling their share or existing uses under Article 14(b)". This shows the unchanged position of Egypt, its securitization hegemonic tactic and hegemonic solution which is cooperation in view of producing more water.

3.1.2.2. From Existing Treaty Regime to 'Water Security': The Road to Securitization

The agenda of replacing article 3 (15) and Article 14 by a more progressive clause was first introduced in the immediate close door Nile-COM meeting in march 2006 at Addis Ababa ${ }^{6}$. The justification is that the intromission of water security will serve as 'constructive ambiguity' and as solution to the long-lasting deadlock in the $\operatorname{Basin}^{7}$ (Amare, 2009 as quoted in Dereje, 2011:360) which has paradoxically became a point of negotiation. In this case, the question must be is constructed ambiguity a hegemonic power tool to advance its interest and to prolong the lifespan of the status quo or a counter hydro hegemonic tool used by non-hegemonic riparians with the intent of transforming the already established order? Although the aforementioned reason for the intromission of 'water security' into CFA is generally to accommodate the divergent views of upstream and downstream countries, it has neither break the deadlock nor brings divergent views into compromise. Rather the concept 'water security' is used by Egypt as a cover to shield the status quo. The proposed clause by Egypt shows this fact which can be read as "...the water security of each Nile basin state, in particular, current rights

http://www.gcao.gov.et/documents/10184/19296/L10-The+Nile+BasinAgreemen.pdf/7a063de9-9e08-4585-9a32-c3bfaf1a9490?version=1.0 ${ }^{1}$ Final Report of Transitional committee of the Nile river basin cooperative framework project (D3) to Nile Council of Ministers of Water Affairs. Draft agreement on the Nile river basin cooperative framework. August 2001, Entebbe.

${ }^{2}$ Minutes of the second negotiation committee meeting (8-12 March 2004). Nile River basin cooperative framework project. Entebbe, Uganda; Minutes of the seventh negotiation committee meeting (5-9 December 2005). Nile River basin cooperative framework project. Entebbe Uganda.

3 Mona Sewilam talks to experts John Rao Nyaoro, Executive Director of NBI, and Dr. Mahmoud Abu- Zeid, former minister of water $\begin{array}{lllllllll}\text { resources } & \text { and } & \text { irrigation } & \text { of } & \text { Egypt } & (1997-2009) & \text { Retrieved } & 30 & \text { April }\end{array}$ http://www.dehai.org/archives/dehai_news_archive/2015/aug/0002.html

${ }^{4}$ Dr. Mahmoud Abu- Zeid, Supra Note 17

${ }^{5}$ Dr. Mahmoud Abu- Zeid, Supra Note 17

${ }^{6}$ Ministry of Water Resource (May 1998). The $14^{\text {th }}$ Nile ministerial council meeting report.

${ }^{7}$ Cascão, Ana Elisa (n.d.), Use of Ambiguity in Transboundary River Basins Negotiations: The Case of the Nile River Basin, Department of Geography, King's College of London, United Kingdom. Retrieved On: 07 July 2016 From Https:/Www.Researchgate.Net/Publication/254978045 
and uses of Egypt and Sudan which are based on previous agreements" ${ }^{1}$. Here my argument is that the intromission of 'water security' into CFA is a hegemonic bit so as to inject CFA with the intent of paralyzing CFA and making it inefficacious and symbolic.

\subsubsection{General Principles and Use of Terms}

Another contentious issue is on use of terms: Nile River Basin vs. Nile River System. The position of Ethiopia is that both terms should be used in appropriate place based upon the context which means that 'Nile river system' refers to Nile waters use and impacts while 'Nile River basin' refers territories, conservations and protections ${ }^{2}$. Article 3 of the original drafted document uses the term 'Nile River basin'. Ethiopia has a reservation on this clause and proposed that "the Nile river system shall be protected, used, conserved and developed in accordance with" the listed principles under Article $3^{3}$. However, an agreement was reached later on and the final document that was opened for signature incorporates both terms in which Nile river system is to be used in referring utilization of water while Nile river basin to refer 'environmental protection, conservation and development ${ }^{4}$.

Although all countries including Egypt have agreed on the use of these terms currently Egypt is backfiring ${ }^{5}$. Egypt is now arguing that the use of the term 'Nile river system' in Article 2 (b) is an act of breach of NBI shared vision. This is another tactic of Egypt in shielding its interest. According to the former minister of water resources and irrigation of Egypt (1997-2009) Dr. Mahmoud Abu- Zeid, the provision of Article 2(b) was replaced by 'Nile river system' which is at odds with Egypt's proposal ${ }^{6}$. The Nile river system implies only the water that flows into the main Nile while Nile river basin includes all the water resources of the concerned State. The implication is that if Nile river basin is used in the document then alternative water sources will be taken into account in time of equitable entitlement. This will give Egypt an extra bargaining power which is reinforced by the dual discourse of absolute dependency and alternative sources.

\subsubsection{Prior Notification/Planned Measures}

This is another contentious issue. The clause concerning planned measures is article 8. Ethiopia has reservation throughout the negotiation and it has called for the removal of all provisions of article 8 . The justification is that for the current framework the provision of 'information and data exchange' as outlined in Article 7 is sufficient and issue of planned measures will be raised and become relevant if and only if equitable water sharing acceptable for all countries came to effect ${ }^{7}$. However, an agreement was reached to exchange information and data through the Nile river basin commission and for this the commission will establish rules and procedures (CFA, Article 8 sub articles 1 and 2).

Although Egypt has agreed on all provision of CFA with the exception of Article 14 (b) its position on prior notification is now revitalized. Egypt's officials (Dr. Mahmoud Abu- Zeid, 2015) and government organs (Centre of Judicial Studies and Research Department of Arab Republic of the State Council, 2013) asserted that procedures and rules on prior notification must be agreed and included in CFA. The Centre of Judicial Studies and Research department of Arab republic of the State Council recommends that upstream countries have violated the procedure of NBI. According to their recommendation paper, this along with the signing of CFA without ending the negotiation will accord Egypt to reopen the issue and come up with a text that "include the rights and current uses of Egypt and the inevitability of a prior notification before establishing any project on the Nile. This should come according to the notification measures adopted by the World Bank (WB) in this respect". The current Egypt high level visit to the equatorial Lake region has to do with this as the State Information Service of the Arab Republic noted that the main focus of the visit of Egypt foreign minister Sameh Shoukry to Uganda is to "achieve consensus among the Nile Basin countries in light of Ugandan's current presidency of the

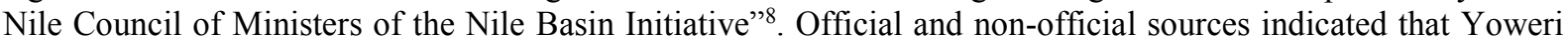
Museveni has called Summit of Heads of States of the Nile basin countries aimed at discussing on CFA ${ }^{9}$. The intention of Egypt is to open CFA for renegotiation which is now being signed and ratified by six and three countries respectively ${ }^{10}$. If this is the scenario then the Summit will be destructive summit.

\footnotetext{
${ }^{1}$ Ministry of Water Resource, Supra Note 20

${ }^{2}$ Minutes of the seventh negotiation committee meeting (5-9 December 2005). Nile River basin cooperative framework project. Entebbe, Uganda.

${ }^{3}$ Minutes of the second negotiation committee meeting (8-12 March 2004). Nile River basin cooperative framework project. Entebbe, Uganda

${ }^{4}$ Agreement on the Nile River Basin Cooperative Framework, Supra Note 13, Article 2

${ }^{5}$ Interview with Fekahmed Negash, Supra Note 3

${ }^{6}$ Dr. Mahmoud Abu- Zeid, former Minister of water resources and irrigation of Egypt (1997-2009), Supra Note 17

${ }^{7}$ Ministry of Water Resource (May 1998). Supra Note 20, p 19; Minutes of the seventh negotiation committee meeting. Supra Note 23, Article 8 reservation Note.

${ }^{8}$ State Information Service of the Arab Republic (01 May 2017). FM heads for Kampala carrying message from Sisi to Ugandan president.

Retrieved 30 April 2017 From http://www.sis.gov.eg/Story/108895?lang=en-us

9 Interview with Fekahmed Negash, Supra Note 3

${ }^{10}$ Interview with Fekahmed Negash, Supra Note 3
} 


\subsubsection{Majority Vote Vs. Consensus}

This is also another contentious issue and till now Egypt position remains unchanged ${ }^{1}$. Egypt position is that decision about 'amendment of the framework or protocol and adoption and amendment of annexes' must be by consensus than majority vote which is at odds with the Ethiopian position ${ }^{2}$. Although the final document listed out provisions to be amended by consensus and two third majority vote ${ }^{3}$, Egypt still want other provisions (article 6,7,10,11,12,13 and 33) to be amended by consensus.

Egypt's position on this provision is another tactic of prolonging the status quo. Decision making by consensus has become popular following its successful employment at the $3^{\text {rd }} \mathrm{UN}$ conference on the Law of the Sea from 1973 till 1982 (Buzan, 1981: 324). According to Berridge (2010:157), consensus decision making is "an attempt to achieve the agreement of all the participants" in a given multilateral institution. It is the process of reaching an agreement by way of consensus without any obstruction from the participant (Movsisyan, 2008:78). With regard to CFA, Egypt used the provision of 'decision by consensus' to denote both the decision process and the decision rule which gives Egypt an extra-bargaining power through objection and reservation ${ }^{4}$. In contrast, upstream countries viewed decision by consensus as a process to reach an agreement in accordance with established 'decision rule' which may range from majority vote to simple majority vote or other ways of making decision. Egypt's view of consensus decision making as a decision by unanimity rather than by vote will enable Egypt to block proposals found inconsistent with its interest. Since a single block of a given proposal is sufficient in stopping the proposal, Egypt's view and position on the provision of consensus is another Egypt's hydro hegemonic tactic to maintain the status quo.

In general, consensus decision making in river basin known of sensitive issues like Nile has dire consequence. First, consensus based decision will give Egypt extra-bargaining power and an incentive to block any proposal inconsistent with the status quo. Thus, Egypt's unchanged position on this provision even after the document moves further steps of signing and ratification is preservation of the status quo. Second, consensus decision making will result stagnation and institutional dysfunction. Third, since consensus based decision may result blocking of decision and long period meetings and negotiation it may led to end of multilateralism. Thus, this is Egypt's tactic of 'divided and rule'. Finally, it may led to the perception that the unfair status quo being canonized and shield by downstream countries is difficult to change unless unilateralism, creation of 'facts on the ground' is pursued. This is particularly true with regard to the announcement of GERD by Ethiopia ${ }^{5}$.

\subsubsection{Counter Hydro Hegemonic Role of CFA}

CFA will have a legal effect if it is ratified by all riparians or at least by six countries. As of the writing of this paper, CFA was ratified only by three countries. It has also faced several problems because of several reasons. Therefore, in the meantime CFA will not have legal value but political and counter hydro hegemonic role. In view of that, this section discusses the counter hydro hegemonic role of CFA.

\section{Breaking of Hegemonic Consent}

The initial step in the long journey of transforming a hegemonic order thereby forging of a new playing field is breaking of consent. Here the first question must be is there any consent to the hegemonic order in the Nile River? In the Nile river basin, Egypt hydro hegemonic position is not based on positive and active consent or 'spontaneous' consent in the words of Gramsci. As hegemony is always contestable, often unfinished process, Egypt hydro hegemony is contested malign hegemony. Other countries have never blessed the status quo created by colonial and post-colonial agreements. Nevertheless, Egypt has incessantly worked hard to convince riparians to subscribe and comply with the values and norms created by itself that is inherently inequitable. However, the created order has not obtained active consent of others. Nevertheless, this does not signify total absent of consent. Rather there is 'obscured consent' which varies from party to party. For Gramsci, consent is "a contradictory consciousness mixing approbation and apathy, resistance and resignation" (Lears, 1985:750) and thus the dominant group can never manufacture consent in its complete form. In view of that, there is no 'apparent consent' to hegemonic created water arrangement of the Nile river basin but only 'veiled consent' 'that can be explained by several reasons.

First, the participation of countries, though not all, in the attempted hegemonized cooperative frameworks such as Undugu, Hydromet and TECCONILE, foreshadows 'veiled consent'. Zerihun (2013) has explained these cooperate efforts as 'pseudo cooperation' aimed at protecting downstream interests. In line with my analysis, these cooperative efforts are an attempt of hegemonization and thus hegemonized cooperation. Second, upstream countries inability in creating 'facts on the ground' because of several factors along with some countries minimal interest in prioritisation of Nile waters also foreshadows 'veiled consent'. Third, occasional based verbal

\footnotetext{
${ }^{1}$ Interview with Fekahmed Negash, Supra Note 3

${ }^{2}$ Ministry Water resource (May 1998), Supra note 20, Pp. 10-12

${ }^{3}$ Agreement on the Nile River Basin Cooperative Framework, Supra Note, 8, Article 36(3)

${ }^{4}$ Interview with Fekahmed Negash, Supra Note 3

${ }^{5}$ Interview with Ana Elisa Cascão (PhD), Supra Note 2

${ }^{6}$ Interview with Ana Elisa Cascão (PhD), Supra Note 2
} 
contestation shows assent or at least acquiescence. This 'veiled consent' varies from country to country, however. With gradually this 'veiled consent' is now changed into 'apparent contest'. From this it can be concluded that the kind of hegemony is not hegemony based on active and positive consent. Rather it is contested malign hegemony with veiled consent and apparent contest.

In this case, CFA has a crucial role in challenging the status quo created by amorphous colonial agreements. Prior to CFA, there was verbal contestation against the hegemonic order. However, because of various reason verbal contestation has never translated into action until the opening of CFA for signature and the unilateral move of Ethiopian hydraulic mission. One of the game changer in the hydropolitics of Nile is thus the upstream countries unanimous decision to open CFA for signature without downstream countries at 2009 Nile-COM Sharm El-Sheikh meeting. The aforementioned Nile-COM meeting shows the translation of 'veiled consent into an actual contest' of the status quo. In an interview with Egypt state TV, the late Prime Minister Meles Zenawi said that the opening of CFA for signature is the reflection of two things: "expression of upper riparian countries frustration and dissatisfaction with the status quo and their desire and commitment to the new alternative which is a win-win"1.

However, this must be seen as a continuation not as a departure. Non-hegemonic countries have contested the 'phantom status quo' established by inefficacious agreements starting from the eve of the legalization process of the hegemonic status quo. The first known non-hegemonic unified position is the 'Nyerere Doctrine on State succession' that colonial treaties are non-binding if incompatible with state interest ${ }^{2}$. Particularly three upstream countries- Tanzania, Uganda, Kenya- have adopted this position (Kasimbazi, 2010:726-728). However, they failed to convert their position into reality. Thus, the signing of CFA is a continuation of past efforts and it is consequential in making the unfair regime an end.

What makes the 2009 Nile-COM Sharm El-Sheikh meeting special is thus its implication for the hydropolitical status quo. First, it strongly shown that upstream riparians are not consenting to the status quo and thus disrupting Egypt's hydro-hegemony ${ }^{3}$. Second, it is the only decision made by all non-hegemonic riparians excluding downstream countries as Cascão noted that "the seven upstream riparians, forming one single block for the first time in Nile history, accepted this formulation as an acceptable departure, potentially helpful in accomplishing the conclusion of the CFA" (Cascão, 2012:244). Thus, non-hegemonic riparians have proven their commitment in bringing the already unfair Nile regime an end. Third, a new historical non-hegemonic block was initiated by a conscious political force engaged in conscious planned struggle which intends to establish a new order: making their shared resource governable through a permanent comprehensive legal and institutional framework. This historical block has brought their unilateral position on existing treaties and holds a common position with a clear-cut decision that the 1929 and 1959 unilateral agreements are null (Kasimbazi, 2011:753a). This is exceptionalism in the hydropolitical history of Nile. Along this, the non-hegemonic riparians decided to move onto signing and ratification even without downstream countries. This shows again the determination of non-hegemonic riparians in transforming and thereby creating a new order.

\section{Transformative Role of CFA}

CFA as an alternative system of water arrangement has a transformative role. From the beginning CFA has challenged the already established order which is against the very right of non-hegemonic riparians. First, it envisioned a new order based on principles of equity. The very raison d'être of CFA is to enable Nile river basin countries to determine equitable entitlements of their shared resources and to enhance and promote the utilization of the common shared Nile waters for optimal sustainable socio-economic benefits of the inhabitants of the basin $^{4}$. Thus, CFA is a departure visualizing the creation of new order based on the complementarity principle of 'equitable and reasonable utilization' and 'not to cause significant harm' with due emphasis to the protection, conservation and governance of the Nile waters for optimal use for all regardless of their geographical position ${ }^{5}$. Thus, transforming the unfair status quo is the very raison d'être of CFA.

Second, CFA is a major departure as it is an all-inclusive agreement. Third, CFA has attempted to make Nile basin countries water secured through the provision of the complementary principle of 'equitable and reasonable utilization' and 'not to cause significant harm ${ }^{6}$ '. Fourth, it attempted to change unilateralism and competition into cooperation based on outlined principle and it also gives due emphasis to the conservation of the River ${ }^{7}$. Finally, it has introduced conflict resolution mechanisms if countries feel that they are not water secured. All in all, CFA has a transformative role.

\footnotetext{
${ }^{1}$ Prime Minister Meles Zenawi Interview with Egyptian TV on Nile Issue part 2 of 4 [Video File], Available at www.hebrezema.info https://www.youtube.com/watch?v=Gc2TJzXpht0

${ }^{2}$ E-mail correspondence with Professor Anthony Turton, Supra Note 6

${ }^{3}$ E-mail correspondence with Rebecca L. Farnum, Supra Note 5

${ }^{4}$ Panel of Experts (1999), Supra Note 7

${ }^{5}$ Interview with Dereje Zeleke (PhD), Supra Note 13

${ }^{6}$ Interview with Tewodros Tefera, Expert at Boundary and Transboundary River Affairs Directorate General, Ministry of Water, Energy and Irrigation, 30 February 2017

${ }^{7}$ Interview with Tewodros Tefera, Supra Note 43
} 


\section{CFA Role in Creating Counter Hydro Hegemonic Narrative}

The very raison d'être of CFA as discussed above is an instrument that promised to spifflicate the Nile history of 'legicide'. It envisioned to create an enabling environment for the optimal utilization of the Nile River. The realization of such objective however requires ratification which is now become a delayed process. Apart from ratification, there are necessary requirements on the part of non-hegemonic riparians.

First, CFA will not have legal life in the meantime because of the hegemonic diplomatic clout and tactic which is best described as an attempt of 'legicide'. In this case, what is needed from the non-hegemonic riparians is 'historicide'; destroying the hegemonic constructed knowledge and discourse on which Egypt's Nile identity of inseparability was constructed for millennia and thereby preventing the transmission of ideas embodied the current status quo. Success in this front is the single-most prerequisite in creating a new order, discourse and knowledge on which a new common identity will be created. Second, CFA will not have pragmatic effect unless 'facts on the ground' is created'. According to Raslan Hani, Egyptian political analyst, there is no reason for Egypt to sign CFA because what matter is important 'facts on the ground', the commencement of upstream hydraulic projects ${ }^{1}$. Along this the creation of 'a historic non-hegemonic block' is more consequential at least for two reasons. First, they can successfully create a consistent counter hydro hegemonic narrative using CFA as a ladder. Second, it will enable upstream riparians to mobilize their resources to engage in large hydraulic mission which will (in) directly affects the follow of the Nile waters (Abadir, 2011:310). Given that downstream countries are geographically in a disadvantageous position, the success of non-hegemonic riparians in these two paths will significantly weaken the hydro hegemonic position of Egypt. This shows that the success of CFA is largely determined by the non-hegemonic countering effort and tactics.

In this case, CFA has a role in creating a counter hydro hegemonic narrative. Abadir (2011) argued that the introduction of CFA is more to do with counter hegemonic value than legal value and "CFA is best explained as a first step to counter and undo the hegemonic actions of Egypt that have been instigated since the beginning of the nineteenth century". Thus, CFA has a special importance in creating counter hydro hegemonic narrative which are discussed as follows.

\section{Demystifying the Downstream Narrative of 'Historical and Acquired Right' Via Principle of 'Equitable and Reasonable Utilization'}

Downstream countries claims 'acquired and historical rights' of the Nile waters and such claim of right is also codified and institutionalized through inefficacious colonial and bilateral agreements of which the 1929 and 1959 agreements serves as the legal foundation of their 'historic right' ${ }^{2}$. The claim of 'acquired and historic rights' has been an impediment of Nile cooperation. In contrast, CFA has adopted an international water law principle, 'equitable and reasonable utilization with a duty of not to cause significant harm', that reconciles and balance the conflicting interest of downstream and upstream countries ${ }^{3}$.

However, in the view of downstream countries, this principle is against their claim of historic right because the principle of 'equitable utilization' is governed by the principle of sovereignty: "every riparian states has a right to the utilisation of the watercourse which is qualitatively equal to the rights of the co-riparians" irrespective of their geographical position and claimed vested rights ${ }^{4}$. CFA gives each country the right to use the Nile waters in their respective territorial jurisdiction in accordance with principles outlined in the document ${ }^{5}$. Thus, CFA provides an equity, reasonable and fairness based principle alternative to the inequity and dysfunctional principle of 'acquired and historic rights'.

The principle of 'equitable and reasonable utilization' requires countries sharing water resources to use it in a manner that is equitable plus reasonable which is determined by taking into account all relevant factors and circumstances as outlined in the framework of agreement. This principle neither supports 'established uses/historical rights' nor establishes a new uses a priori'. Rather its very purpose is to establish balanced system of water utilization among users in view of attaining optimal plus sustainable utilization of the commonly shared water resources ${ }^{6}$.

By using CFA as springboard, therefore, non-hegemonic riparians can create a counter hydro hegemonic narrative. The hydro hegemonic narrative in the Nile river basin is that downstream countries have natural and historical rights and thus any new agreement must recognize and preserve these rights. To counter this hegemonic narrative, non-hegemonic riparians could use CFA as starting point of departure to moves onto practicing their claim of sovereign rights over water resources within their territorial jurisdiction. Along this, narrative of Nile as a common property of all habitants of the Nile basin as opposed to the historical illogical and

\footnotetext{
Raslan, Hani (22 June 2011). Controlling the Nile. Retrieved 19 March 2017 from http://www.aljazeera.com/programmes/struggleoverthenile/2011/06/2011619152153129827.html.

21929 Agreement, Article 2; 1959 agreement, Article 1 (1-2).

${ }^{3}$ Agreement on the Nile River Basin Cooperative Framework, Supra Note 8, Article 3 (4 and 5)

${ }^{4}$ UN (n.d.). Equitable and Reasonable Utilization. UN Watercourses Convention User's Guide Fact Sheet Series: Number 4. Retrieved 8 march 2017 from http://www.unwatercoursesconvention.org/documents/UNWC-Fact-Sheet-4-Equitable-and-Reasonable-Utilisation.pdf

${ }^{5}$ Agreement on the Nile River Basin Cooperative Framework, Supra Note 8, Article 3(6)

${ }^{6}$ McCaffrey, S. (1999). 'Nile river basin cooperative framework project (D-3) Reports on Principles'.
} 
non-legal base narrative of Nile as Egypt source of life, the father of Egypt', the saviour of Egypt, the giver of life, the creator of Egypt, Egypt as gift of Nile' would be constructed (Ostigard, 2010:2-3). Thus, CFA can serve as a springboard to create counter hydro hegemonic narrative which will erode the hegemonic narrative that has prevailed since antiquity.

\section{A. Developing Narrative of Win-Win Situation as an Alternative to the Win-Lose}

The existing regime is a win-lose even it is against the very legal right of upstream countries. CFA is a departure which envisioned a win-win new order. However, it is not welcomed by Egypt even at worst CFA is declared by Egyptian as win-lose which disregards Egypt's historical share of the Nile waters which is against their right and interest ${ }^{1}$. Former minister of water resources and irrigation of Egypt (1997-2009) Dr. Mahmoud Abu- Zeid declared that Article 2(b) and Article 14 (b) of CFA are a breach of NBI shared vision and the 2014 Constitution of The Arab Republic of Egypt respectively². In this case, non-hegemonic riparians must consistently publicise the unfairness of the existing water regime and the win-win promise of CFA. Confidence and trust building is thus needed and non-hegemonic riparians must reasonably persuade downstream countries about the equity of the new order to be established by CFA.

For long Ethiopia insists the necessity of win-win solution. In an interview with Aljazeera, the late Prime Minister Meles Zenawi suggests the need of 'win-win solution through diplomatic efforts' otherwise Egypt cannot stop the 'unstoppable' Ethiopian unilateral move ${ }^{3}$. With regard to CFA, upstream countries regarded it as a new deal envisioning a win-win solution. In an interview with Egypt State TV, Meles Zenawi said that "the first step for cooperation is recognition of each other's interest and recognition of the need of win-win situation that is what lacking now"4. Here there are two narratives. The downstream narrative insists that only the interest of two countries matter as they have no alternative source of water other than the main Nile. In contrast, Ethiopia maintains that prior to any cooperative efforts there is a need of recognition of the necessity of win-win solution alternative to the win-lose existing status quo. Thus, using CFA as a ladder a narrative of new alternative winwin situation to the win-lose 1959 bilateral agreement, which takes 'Sudan and Egypt as stakeholders while upstream countries as beggars', can be developed ${ }^{5}$. The narrative of win-win solution aimed at optimal and sustainable use of Nile waters can be epitomized via CFA. The realization of this situation requires three things, however. First, the hegemonic narrative of 'Nile waters are belong to Sudan and Egypt' must be dispel. Second, fairness and equity must be adopted as the guiding principle of the new order. Finally, recognition of each other interests and rights must be assured.

\section{B. Desecuritization Vs. Securitization}

One of the hydro hegemonic compliance mechanisms used by Egypt is securitization as it considers water as an existential issue. The hydro hegemonic narrative is that Egypt is absolutely dependent on the waters of Nile and thus water is a national security issue. In view of that, Egypt insist that upstream countries have alternative sources other than the main Nile for whom water is not existential threat. In this case, non-hegemonic riparians come to realize the need to counter hegemonic securitization narrative. Non-hegemonic riparians are attempting to desecuritise using CFA as a point of departure. For instance, in an interview with Egyptian State television, the late prime minster Meles Zenawi confirms that CFA envisioned for the benefit of all states concerned and it does not aimed to affect downstream interest ${ }^{6}$. He stressed that "upstream countries do not have the agenda benefiting at the expensive of Egypt and Sudan"7. Thus, he provides a desecuritized even morally sound counter narrative. Thus, using CFA as a ladder upstream countries can launch non-securitised narrative as opposed to the securitised narrative of Egypt.

\section{C. 'We Need Nile for Development' Vs. 'You Can Live Without Nile'}

Another hydro hegemonic narrative is that Egypt viewed itself as a country whose life is absolutely dependent on the Nile waters while the others have alternative sources and thus can live without Nile. However, using the discourse of poverty reduction and the right to development, non-hegemonic riparians particularly Ethiopia is providing an alternative narrative of 'we need Nile for development' as opposed to hegemonic constructed narrative of 'you can live without Nile'. The decade negotiation process and also the signing and ratification of CFA in this regard shows the upstream determination and commitment in using the Nile waters in a fight against

\footnotetext{
${ }^{1}$ Robert Iskandar, Egypt's former Ambassador to Ethiopia, in an interview to The Cairo Post. Ramzy, Bishoy (20 March 2014). Kenya to ratify Entebbe Agreement, Egypt experts express fear. The Cairo Post. Retrieved April 2017 from http://thecairopost.youm7.com/news/103055/inside egypt/kenya-to-ratify-entebbe-agreement-egypt-experts-express-fear

${ }^{2}$ Article 44 of the 2014 Constitution of The Arab Republic of Egypt state that "the State shall protect the River Nile and preserve Egypt's historical rights". Even the preamble states about the inseparability of Nile and Egypt which can be read as "Egypt is the gift of the Nile for Egyptians and the gift of Egyptians to humanity”. For more see Constitution of The Arab Republic of Egypt 2014; Egypt State TV Interview with Mahmoud Abu Zeid, 2015

${ }^{3}$ Talk to Aljazeera Meles Zenawi.mp4, Available at https://www.youtube.com/watch?v=9S83SVAumsQ

${ }^{4}$ Prime Minister Meles Zenawi Interview with Egyptian TV on Nile Issue part 4 of 4 [Video File], Available at www.hebrezema.info https://www.youtube.com/watch?v=8jPqauRINBc

${ }^{5}$ Prime Minister Meles Zenawi Interview with Egyptian TV, Supra Note 54

6 Prime Minister Meles Zenawi Interview with Egyptian TV, Supra Note 54

${ }^{7}$ Prime Minister Meles Zenawi Interview with Egyptian TV, Supra Note 54
} 
poverty. Thus, CFA came up with a new narrative of 'Nile waters for the current and future generation of all inhabitants of Nile' as opposed to the narrative of 'Nile as scared gift of the past, present and future generation of Egypt alone'.

\subsection{Resource Capture as a Coercive Counter Hydro Hegemony Mechanism}

The other more consequential counter hydro hegemony mechanism is resource capture which may occur when the more powerful group uses their power and wealth to shift the resource in their favour (Homer-Dixon, 1999:15 and 73). A resource capture strategy is just the unilateral move of a riparian in hydraulic mission which (in) directly affects the flow of the water. Using geographical, material and expert power upstream country can control the resource. One of a resource capture strategy is multipurpose hydraulic infrastructure (Warner and Mark, 2006:444). In this case, Ethiopia has not yet developed its water resources to the optimal level because of lack of financial resource, protracted internal and external conflict, week expert power and also discontinuity of water experts as a result of political instability (Abate, 1994 as quoted in Cascão, 2009:254; Waterbury, 2002:72; Yacob, 2010:169). Although such problems hindered the development of water resources, the three successive regimes showed strong determinism and commitment in building hydraulic infrastructure aimed at 'fighting poverty' (Waterbury, 2002:126).

The three successive regimes have attempted to follow hydro-agrarian State building strategy. Since the second half of the $20^{\text {th }}$ century, Ethiopia has engaged in hydraulic mission and now it is building a more consequential dam, GERD, which is viewed in the contemporary literature as 'game changer' (Tawfik, 2016:577; Cascão and Alan, 2016:550; Zerihun, 2016), 'new legal order' (Salman, 2016:14) and 'fair system'(Rieu-Clarke and Zeray, 2016:544). But it must be noted that GERD is not a point of departure rather it is a continuation of the unreserved efforts of Ethiopian leaders regardless of regime type ${ }^{1}$. On this account, the resource capture plan of Ethiopia goes back to the imperial regime and since then Ethiopia has implemented several hydraulic infrastructures. This section, therefore, first moves onto describing Ethiopian hydraulic plan and engagement in the three successive regimes along with the potential effect on the hydro political dilemma of Nile. This will be followed by analysis of the hydro political consequence of GERD in eroding the hydro political status quo of Nile.

The three successive Ethiopian governments have viewed big hydraulic project as a viable strategy to attain food security and to mitigate poverty which is an 'element of continuity' (Waterbury, 2002:106; Yacob and Imeru, 2004:19). During the imperial regime, a comprehensive study on the Abbay River was conducted known as USA-Ethiopia cooperative programme for the study of the Blue Nile Basin which produced a document entitled 'Report on the Development of the Land and Water Resources of the Blue Nile River Basin of Ethiopia'. Upon the request of Ethiopian government ${ }^{2}$ the US state department Agency for International Development tasked the Bureau of Reclamation of the US Department of Interior to undertake the study of Abbay river, a reconnaissance report on the development of the land and water resources of the Blue Nile river basin of Ethiopia, which is part of the cooperative program between the U.S and the Imperial Ethiopian Government ${ }^{3}$. The survey and study of land and water resources of the Blue Nile Basin was started earlier of 1958 by the Personnel of Bureau of Reclamation ${ }^{4}$. The overall objective of the study was to conduct a study on the land and water resources of the Blue Nile river basin, to help the establishment of institutional mechanism within the Ethiopian government, and to train Ethiopian engineers and technicians ${ }^{5}$. All the three objectives are crucial in in terms of expert and structural power. The study produced six volumes on hydrology, water quality, hypsography, geology, sedimentation, mineral resources, land resources, ground water, and the local socio-economic situation with identified irrigation, hydro power and multipurpose dams. The study proposed a total of 33 projects of these 14 are irrigation, 11 hydro power and 7 multipurpose ${ }^{6}$.

Despite this ambitious plan with a direct consequence on the hydro political status quo of Nile, with the exception of Fincha agro industry it has never been realized because of lack of financial sources both at domestic and international levels (Yacob, 2007:154). According to Yacob (2007:155), the study "resulted neither in an immediate water development project nor in any diplomatic leverage against the down-stream co-riparian states" and thus it shows the politics of the cold war period which can be explained as "you (Egypt) have the Russians

\footnotetext{
${ }^{1}$ Interview with Dereje Zeleke (PhD), Supra Note 13

${ }^{2}$ Initially the U.S State Department was requested by Dejazmach Zewude G/Sellasie whether U.S government would be interested to assist in the study of Blue Nile basin. This has pushed the imperial government to formally request the U.S State Department and the U.S government agreed to participate in the investigation of the comprehensive study of Blue Nile basin. The project costs Ethiopia 420 million birr. Dejazmach Zewude G/Sellasie (2000). The Nile River questions in a new era of cooperation among riparian States, Key notes on VIII Nile 2002 conference proceedings, Addis Ababa June 26-29, 2000, p 253-524.

${ }^{3}$ Bureau of Reclamation (1964). Land and Water Resources of the Blue Nile Basin Ethiopia. Prepared for the department of State Agency for International Development. Pp. i-iii.

${ }^{4}$ Bureau of Reclamation, Supra Note 60, p 3

${ }^{5}$ Bureau of Reclamation, Supra Note 60, p. iii.

${ }^{6}$ Bureau of Reclamation, Supra Note 60, pp.167-300.
} 
and the Aswan High Dam, but we [Ethiopia] have the United States and, more important, the water" (Waterbury, 2002:69).

In contrast to such views, I argue that although the study program shows the very politics of the day, it has an implication to the existing status quo which is established by bilateral agreements and thus it must be viewed as a point of departure in transforming verbal contestation and Ethiopian developmental aspiration of water resources into action. Firsts, it sends a message to Egypt about Ethiopian readiness, determination and commitment in moving onto hydraulic mission which is unstoppable in the near future. Second, it shows the coming of opportune time for upstream countries to exercise their claim of rights. Third, it has increased Ethiopian expert and structural power with regard to water resources. In terms of expert power, one engineer and 150 lower level Ethiopian professionals had participated in the project and gained training which provides the country with expertise in hydraulic works ${ }^{1}$. In terms of structural power, water resource department was established as an agency under the Ministry of Public Works and Communications which can be viewed as a first step towards an autonomous water institution' ${ }^{2}$. Finally, such planned projects in the eye of Egypt is 'grandplanned threat' and it will be 'actual threat' when such plan translated into action. Thus, the seed was planted in that time which gives later a more consequential and 'game changer dam', GERD.

Developmental aspiration of developing water resources to attain food security also continued under the Derg regime. The Derg regime has made two things: national wide master plan for all Ethiopian rivers basins, and the Tana Beles development project. First, the regime has conducted a preliminary water resource development master plan for all Ethiopian river basins which is the first national wide water resources development master plan ${ }^{3}$. The project was conducted in cooperation with Indian government. The study was completed on the eve of the collapse of the regime in June 1990. The study produces 11 volumes with 12 annexure on topography, hydrology, hydrogeology, agronomy, geology, seismology, environment, and identified projects for large and small scale irrigation, hydro power and multipurpose dams. The study identifies more than sixty major irrigation and multipurpose projects, twenty six medium irrigation schemes and more than 300 hydro power projects. However, neither of them are implemented since the regime was collapsed soon.

Second, the regime launched the Tana-Beles Development Project in 1985 on the Beles River which is a tributary of Abbay largely to resettle drought affected regions of the Northern part of the country ${ }^{4}$. For this the project planned to divert the water of the Lake Tana via tunnel and the water then will flow into the Beles valley. The Italian government agreed to finance the design and construction of part I of the Tana-Beles project, studies and final design of part II, and the construction of part II of Tana-Beles project particularly the Tana-Beles Tunnel $^{5}$. This project is a multipurpose project with a direct consequence on the downstream countries. Nevertheless, it was not completely implemented because of political instability and lack of financial sources. If it was implemented it would be more consequential.

\section{Table 1.2 Ethiopian Hydro Power Projects on the Abbay River}

\begin{tabular}{llllllll}
\hline No & Project Name & $\begin{array}{l}\text { River } \\
\text { Basin }\end{array}$ & Region & Easting & Northing & $\begin{array}{l}\text { Installed } \\
(\mathbf{M W})\end{array}$ & Status \\
\hline 1. & Fincha & Abbay & Oromia & 316215 & 1058323 & 134 & Functional \\
\hline 2. & Tis-Abbay-I & Abbay & Amhara & 338393.1 & 1272689 & 12 & Functional \\
\hline 3. & Tis-Abbay-II & Abbay & Amhara & 345289 & 1270370 & 73 & Functional \\
\hline 4. & Amerti Neshi & Abbay & Oromia & 309105.2 & 1078090 & 97 & Functional \\
\hline 5. & Tana Beles & Abbay & Amhara & 284013.4 & 1313352 & 460 & Functional \\
\hline 6. & $\begin{array}{l}\text { Tekeze-1 (TK- } \\
\text { 5) }\end{array}$ & Tekeze & Tigray/Amhara & 472125 & 1475533 & 300 & Functional \\
\hline 7. & $\begin{array}{l}\text { Grand } \\
\text { Ethiopian }\end{array}$ & Abbay & Benshangul- & 73336.68 & 1242349 & $6000 / 6450$ & Under \\
& $\begin{array}{l}\text { Renaissance } \\
\text { Dam }\end{array}$ & & Gumuz & & & construction \\
\hline 8. & Lower Dabus & Abbay & Benshangul- & 50206.29 & 1101645 & 326.28 & $\begin{array}{l}\text { Under } \\
\text { feasibility study }\end{array}$ \\
\hline 9. & TAMS & Baro- & Gambela & 41390.34 & 908798.98 & 1700 & Under \\
& & Akobo & Abasibility study \\
\hline 10. & Jema & Abbay & Amhara & 298844 & 1254518 & 60.4 & Reconnaissance \\
\hline 11. & Nekemte & Abbay & Oromia & 169459 & 1050102 & & Reconnaissance \\
\hline
\end{tabular}

\footnotetext{
${ }^{1}$ Bureau of Reclamation, Supra Note 60, pp. 4-6

${ }^{2}$ Dejazmach Zewude G/Sellasie, Supra Note 59, p 253-524

${ }^{3}$ People's Democratic Republic of Ethiopia (1990a). Preliminary Water Resources Development Master Plan for Ethiopia. Final Report, Vol. 1.

${ }^{4}$ Peoples Democratic Republic of Ethiopia (1990b). The Tana Beles Project Part II General Executive Summery.

${ }^{5}$ Peoples Democratic Republic of Ethiopia (1990a), Supra Note 66
} 


\begin{tabular}{lllllll}
\hline 12. Sor-A & $\begin{array}{l}\text { Baro- } \\
\text { Akkobo }\end{array}$ & Oromia & 345919 & 875725 & 80 & Reconnaissance \\
\hline 13. Sese & $\begin{array}{l}\text { Baro- } \\
\text { Akkobo }\end{array}$ & Oromia & 167718 & 945325 & 30 & Reconnaissance \\
\hline \multicolumn{7}{l}{ Source: Collected data from Hydro Power Development and Dam Administration Directorate Director, Ministry } \\
of Water, Energy & and Irrigation, 2017 & &
\end{tabular}

With the coming power of EPRDF into power in 1991, the political and economic landscape of the country was significantly changed. Like that of its predecessors, the government initiated the study of master plan for twelve river basins aimed at assessing the development potential of the country's water resources. Among these master plan the Abbay River basin integrated development master plan, Tekeze river basin integrated development master plan, and the Baro-Akobo river basin integrated development master plan study are in the Nile river basin system. The new regime proceeds to the development of water resources and it has successfully translated the aspiration into action. In this case, there are several hydraulic infrastructure being constructed, functional, planned and under feasibility study as showed in table 4.2. Of these hydraulic infrastructure the Grand Ethiopian Renaissance Dam is more consequential in the hydro political dilemma of Nile which is the crux of this section.

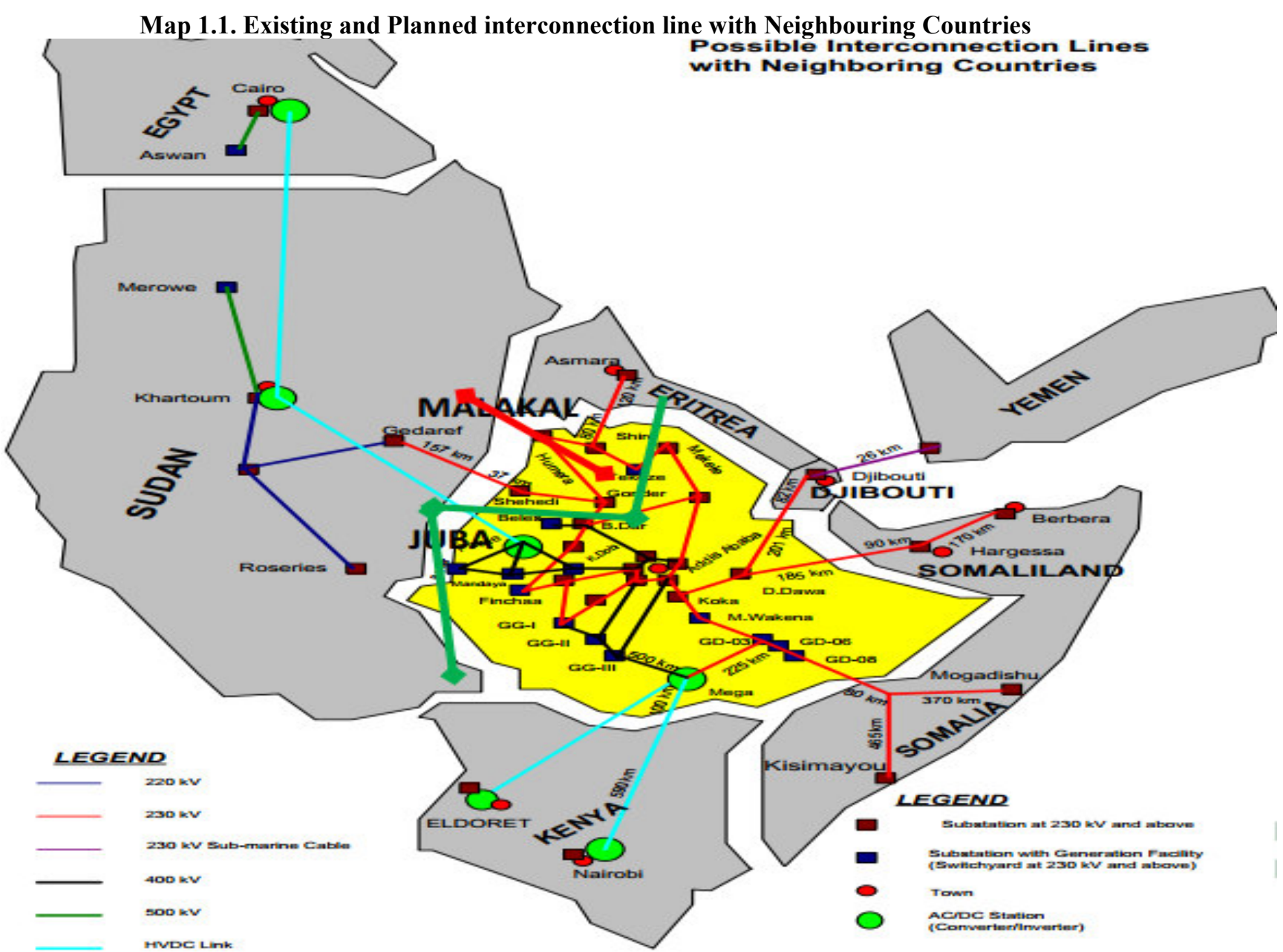

Source: Adopted From Azeb Asnake, CEO, Ethiopian Electric Power, 2015: 19; Yacob, 2016: 26 
Map 1.2. Planned Interconnection in the Northeaster Africa and beyond

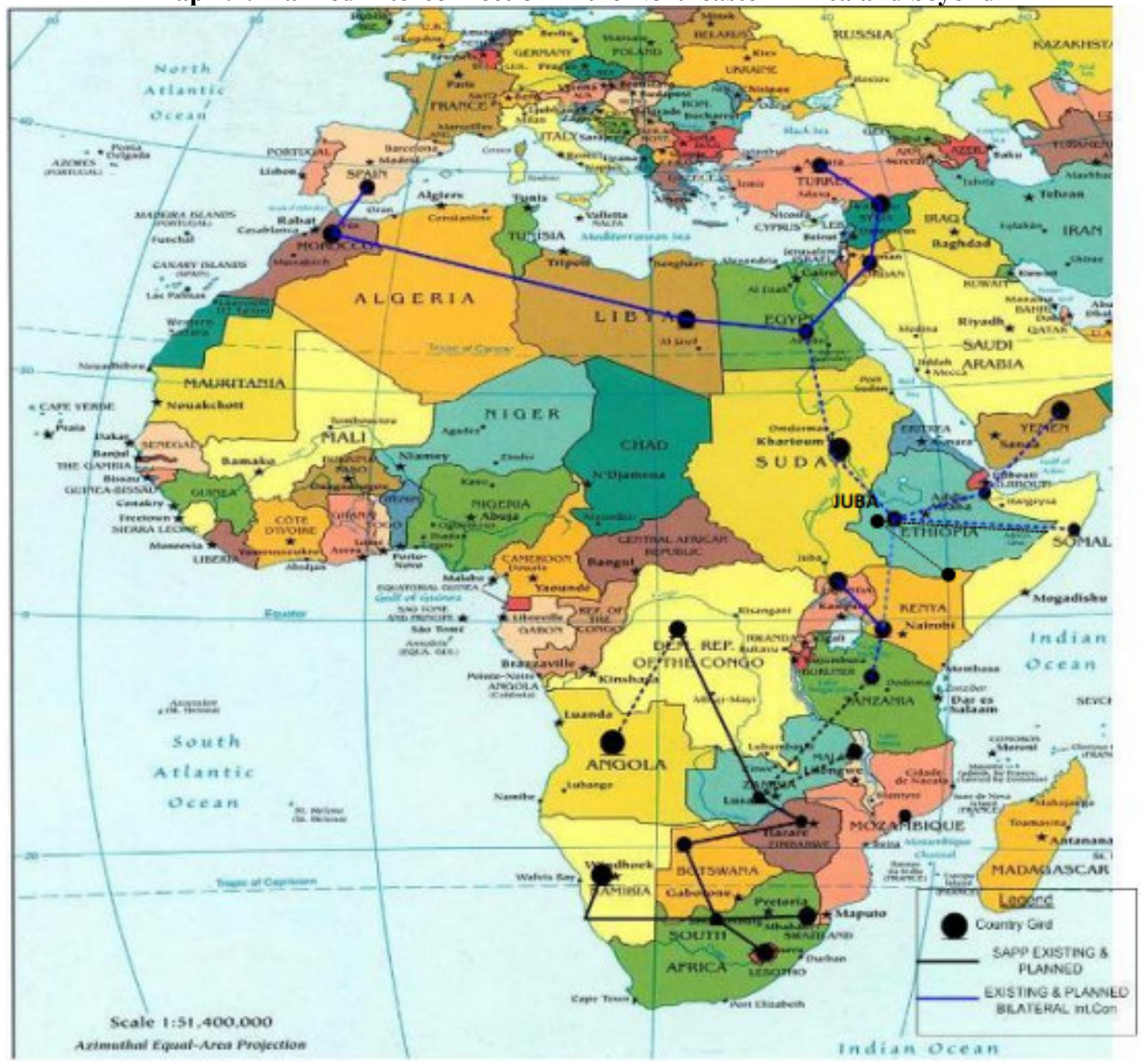

Source: Adopted From Azeb Asnake, CEO, Ethiopian Electric Power, 2015: 20; Yacob, 2016: 27

\subsubsection{Grand Ethiopian Renaissance Dam as a coercive counter hydro hegemony mechanism}

\subsubsection{Grand Ethiopian Renaissance Dam: An Overview}

The Grand Ethiopian Renaissance Dam (GERD) initially known as Millennium Dam project was launched on April 2, 2011 by the late Prime Minister Meles Zenawi. The dam, one of the largest dam in Africa, is located at Guba in the Beneshangul Gumuz Regional state of Ethiopia close to Sudan border (Office of National Council for the Coordination of Public Participation on the Construction of the Grand Ethiopian Renaissance Dam (hereafter Office of National Council), 2017:3). The Dam is anticipated to create a reservoir with a total storage of about $74 \mathrm{bcm}$ and as of the writing of this paper it is projected to produce $6450 \mathrm{MW}^{1}$ (Office of National Council, 2017a:6; 2017b:32) The dam will have a reservoir, the largest Ethiopian man made artificial lake, more than twice of the size or volumetric size of Lake Tana ${ }^{2}$. The cost is estimated to be more than 80 billion birr or 4 billion dollar (Office of National Council, 2017b:32). The source of finance is domestic mobilization of sources largely through donation and buying of treasury bonds. The project is adumbrated as non-consumptive as its very purpose is hydropower generation.

The construction of GERD began as of 2011 coinciding with the signing of CFA and the outbreak of 'Arab spring' that toppled President Hosni Mubarak. With the commencement of GERD Ethiopia moves from grandplan to grand action. Ethiopia has showed its determination in excessing its right over its water resources. As of

\footnotetext{
${ }^{1}$ As of the commencement date of the project it was estimated to generate $5250 \mathrm{MW}$ but later on projected to be $6000 \mathrm{MW}$. Currently, due to an improvement on the design of the dam the generating capacity of the dam has increased to 6450MW as announced by Minister of Communication and Information Technology, Dr Debretsion Gebremichael, in a press conference.

For more See Speech of Prime Minister Meles Zenawi at the official commencement of the Millennium Dam project, 2 April 2011, Retrieved March 2017 from http://www.meleszenawi.com/ethiopian-pm-meles-zenawi-speech-on-launching-gerd-text-and-videos/.;

Ethiopian News Agency (26 February 2017). Installed Capacity of GERD Improved. Retrieved March 252017 from http://www.ena.gov.et/en/index.php/economy/item/2811-installed-capacity-of-gerd-improved

${ }^{2}$ Speech of Prime Minister Meles Zenawi at the official commencement of the Millennium Dam project, Supra Note 98
} 
the launch of GERD, downstream countries reacted negatively with a strong protest against the Ethiopian decision of building dam on Abbay River. The contentious issue raised by downstream countries are the potential downstream consequence of GERD, reservoir filling strategy and time, and overall technical aspects of dam design. Finally under the altruistically invitation of Ethiopia the three countries come to the negotiation table which leads to the DOP and the recognition of Egypt about the reality of the dam.

Before scrutinizing and analysing the role of GERD in challenging Egypt's hydro hegemony and in levelling a new playing filed it seems worthwhile to examine what makes GERD a counter hydro hegemonic tool. First, as discussed earlier, for the status quo to be gone there must be 'facts on the ground'. GERD was announced after a year of the signing of CFA by six countries which is declared by downstream countries as a breach of NBI shared vision. Egypt and Sudan freezes their membership from NBI/ENTRO as a countering tactic. Ethiopia remains the only active member of ENTRO and the future of ENTRO itself and its identified joint projects has become controversial. This necessitated the imperative of unilateralism, establishing a resource capture infrastructure as way of exercising rights. This makes GERD a tool from challenging Egypt's unnegotiable position on 'acquired rights' into changing the order. From the very announcement day of GERD, Ethiopia declared the project as benefit sharing project for the three countries concerned. As argued by Cascão, counter-hegemonic tactics can "challenge unequal hydro-political configurations and, eventually contribute towards a more sustainable and equitable water and benefit-sharing regime" (Cascão, 2008: 13 as quoted in Tawfik, 2015:6). Thus, GERD is a countering tool aimed at ending Egypt's hydro hegemony and leveling of a new playing filed based on principle of equity. Second, GERD was announced in a time of political and economic crisis inside Egypt. This is another reason that make GERD a countering tool envisioned the creation of a benefit-sharing regime the so-called an emergent new order. The following section discusses the role of GERD in countering sanctioned discourse and hydro hegemonic narrative before and after GERD.

\section{GERD as Ways of Exercising Rights}

Ethiopia along with other upstream riparians has claimed the right to use their water resources for development. Despite their assertion, they failed to exercise their right because of several factors. It is thus GERD that shows Ethiopian determination in exercising its 'inviolable right' in developing water resources to attain food security and also to mitigate poverty ${ }^{1}$. It has a crucial role in showing the possibility of building hydraulic infrastructure within ones territorial jurisdiction without access to foreign finance and hegemonic blessing ${ }^{2}$. Historically, Egypt has opposed whatever hydraulic infrastructure in upstream countries even projects that are non-consumptive and beneficiary. Egypt is saying 'you should live with poverty' ${ }^{3}$. However, upstream countries have a right to use their water resources to get rid of poverty. On the commencement day of GERD, the late Prime Minister Melese Zenawi stated that "nothing can stop us from exercising our rights; the other dams we plan to build are less challenging than this, the Millennium Dam. So, the first message is that we not only have a plan, but we also

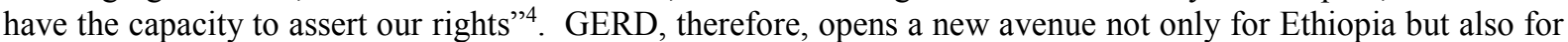
other upstream countries. Thus, GERD has translated the claim into action.

\section{As Coercive Mechanism for Egypt in Recognizing Ethiopian Right}

Since the TeccoNile ministerial meetings Egypt has recognized, though only in principle, the right of Nile river basin countries in utilizing the shared water resources and at the same time Egypt insist that priority must be given to regional cooperation than issue of water allocation (Senai, 1995). For Egypt regional cooperation is in view of collecting and sharing of hydrological data. This is an element of continuity in Egypt's Nile policy. In contrast, Ethiopia consistently held that prior to regional cooperation equitable entitlement of Nile waters for all countries must be made. The position of other upstream countries is not consistent though all countries advocate the need of regional cooperation and equitable entitlement. In practice, however, Egypt has not accepted the right of upstream countries in building hydraulic infrastructure. It is thus GERD that coerced Egypt in recognizing the right of Ethiopia not only in principle but also in action.

Egypt has acknowledge the right of Ethiopian in building the dam. The Declaration of Principles (hereafter DOP) which was signed in Khartoum on March 2015 by Egypt, Ethiopia and Sudan recognizes the right of the three countries in utilizing the water resources of Nile in their respective territories with the duty of not causing significant harm and by taking into considerations relevant guiding factors ${ }^{5}$. This is the single most important change in the hydropolitics of Nile which is not even seen in the decade of CFA negotiation. Agreed minutes of the Nile-COM ministerial meetings, the PoE, negotiation and transitional committee meetings portrays that Egypt has determined not to give even a drop of water for upstream countries whose water is feeding Egypt. Two of the guiding factors article 4 (H and I) are directly copied form article $4(2 \mathrm{H}$ and $\mathrm{I})$ of CFA which is

\footnotetext{
${ }^{1}$ Interview with Tewodros Tefera, Supra Note 44

${ }^{2}$ Interview with Tewodros Tefera, Supra Note 44

${ }^{3}$ Speech of Prime Minister Meles Zenawi at the official commencement of the Millennium Dam project, Supra Note 70

${ }^{4}$ Speech of Prime Minister Meles Zenawi at the official commencement of the Millennium Dam project, Supra Note 70

${ }^{5}$ Agreement of Declaration of Principles between the Arab Republic of Egypt, the Federal Democratic republic of Ethiopian and the republic of the Sudan on the Grand Ethiopian Renaissance Dam project (GERDP), 23 March 2015.
} 
rejected by Egypt and Sudan and ratified by Ethiopia (Salman, 2016:10). This shows that what matter is important 'facts on the ground' which mean hydraulic infrastructure. From this it can be argued that what forced Egypt to recognize the principle of equitable utilization is not CFA but 'facts on the ground' (GERD). From the Egyptian part, it is argued that what forced Egypt to accept the reality of GERD is the changing power relation, sustained economic growth and political stability of Ethiopia, and Egypt's political and economic instability (Tawfik, 2015:1). All in all, GERD has crucial role in forcing Egypt to recognize the right of Ethiopia and the reality of GERD.

\section{Countering Sanctioned Discourse and Offering of an Alternative Discourse}

GERD also provides an alternative countering discourse. Turton (2000:4) has defined sanctioned discourse as "the prevailing or dominant discourse that has been legitimized by the discursive elite within the water sector at any moment in time. It ...leads to the creation of a dominant belief system or paradigm". The existing dominant discourse is two folds. First, Egypt develops a 'right discourse' on basis of its claim of 'historical rights'. The right discourse is not a new fabrication rather it was planted in the minds of ancient Egyptian which is reinforced by mythologies and later institutionalize by colonial and post-colonial agreements. The second discourse is constructed on the basis of the first 'discourse of right'. This includes the discourse of entire dependency vs. alternative sources, discourse of security and upstream countries action as a threat of the natural order. The Egyptian mythologies epitomize their neighbours particularly Ethiopia as enemy of the Nile valley unity which is an element of continuity. When Ethiopia announces the GERD, the Egyptian ruling regime responded negatively and decided to use all means to subvert the dam.

In contrast to this, Ethiopia develops counter discourse such as discourse of the right to development. In this case, GERD offers alternative discourse. First, the discourse revolves around GERD is that GERD is driver of economic development including regional development and thus it is a beneficiary project for the region by making Ethiopia the regional hydro power provider. Second, GERD is a project in getting rid of poverty trap and ending dependency on foreign aid and thereby transforming the image of the country form poor foreign aid dependent country into emergent economy capable of feeding itself and being capable of financing other projects In this case, there is sign of change on the part of Egyptian dominate discourse on the Nile. First, because of the construction of GERD Egypt accepts Ethiopian right to development which is historically non-existent. Second, there is a tendency in shifting Nile from being private resource of Egypt alone into public good. Finlay, with the signing of DoP Egypt came to accept principle of equitable utilization, mutual benefit and not to cause significant harm. Thus, GERD has a crucial role in countering sanctioned discourse and offering alternative new discourse.

\section{The role of GERD in showing the imperative of Genuine Cooperation}

GERD has played a crucial role in showing Eastern Nile basin countries about the necessity of sub-basin cooperation as the only way-out and only path of survival. After following several tactics including war of propaganda against GERD Egypt was forced to accept the reality of GERD involuntary. As a result, Egypt opt cooperation to minimize potential impact of GERD on its water use ${ }^{1}$. Like Egypt, Sudan also initially opposed the dam and joined the negotiation to make sure that the project is not causing appreciable harm to Sudan. Ethiopia on the other hand used the negotiation to show the righteous of the project; ' a right project at right place for the benefit of the region'.

After a long period bilateral and multilateral talks the three countries signed a historic breakthrough deal, Declaration of Principle on GERDP on March 2015. The willingness and determination of the three countries to cooperation is reflected in DoP which adopted established principles of international water law, areas of cooperation, ways of conflict resolution mechanisms, cooperative mechanism on benefit sharing from the project and prevention of any negative impact of the project ${ }^{2}$. This is exceptional in the hydropolitical history of Eastern Nile basin. Thus, GERD can be seen as catalyst and future shaper of cooperation but the likelihood of genuine cooperation is largely depends on the realization of a treaty regime and the agreement of the three countries in following a cooperative filling and operation approach of GERD and also when they reach an agreement on power trade.

\section{GERD roles in creating a new benefit sharing regime}

With the building of GERD, Ethiopia is not only the challenger of Egypt's hydro hegemony but also actual changer. First, GERD has changed Ethiopia's countering Nile policy from occasional based verbal contestation into action. Along this, it also changed Ethiopia's reactive policy into a more proactive and assertive with the creation of 'facts on the ground'. This doesn't mean that current Ethiopian Nile policy is proactive. Second, at the regional level, GERD has levelled a new playing field based on principle of equity. The DoP is the first historical document agreed and signed by the most contributor, moderate but probably future more consumer,

\footnotetext{
${ }^{1}$ Interview with Yacob Arsano (PhD), Associate professor of Political Science and International Relations, Addis Abba University, April 2017

2 Agreement of Declaration of Principles between the Arab Republic of Egypt, the Federal Democratic republic of Ethiopian and the republic of the Sudan on the Grand Ethiopian Renaissance Dam project (GERDP), 23 March 2015.
} 
and most consumer of the Nile waters. GERD is an exemplary of a benefit sharing project for the region.

GERD is thus foreshadowing an emergent new order, benefit sharing regime. Nevertheless, the preconditions for benefit sharing regime is not yet fulfilled. Despite this, GERD provides benefits for the region which includes hydropower generation, evaporation loss with an estimation of $3 \mathrm{bcm}$ per year, flood control in wet season and improved water supply in dry season (regulation of water flow), sediment reduction and regulation of water flow (IPoE,2013:41; Jeuland, Dale and John, 2014: 600; Tawfik, 2015:26).

The benefit of GERD for Ethiopia includes 6450 megawatt hydropower and 15, 700 gigawatt hour annual average energy production, fishery development which is projected to be 5, 000 to 10,000 tons of fish per year, aquatic and terrestrial fauna resources, power trade, avoidance of $\mathrm{CO} 2$ emission, increased expert power and technology transfer, tourism and job opportunity (Office of National Council, 2017a: 8; 2017c: 2). Thus, GERD will make Ethiopia an energy hub in the East Africa. Sudan is also the immediate beneficiary of the project: increases the hydropower generation capacity of its seasonal storage dams, reduce damages as a result of seasonal flooding, increase potential of irrigated agriculture, reduce the cost used to cope with the destruction and for maintenance due to flooding, saving of more water and reduce evaporation, sediment control, navigation opportunity and power purchasing form the project $^{1}$ (Office of National Council, 2017a:9). According to IPoE report, the benefit for Egypt includes "an increase in irrigated area, a decrease in sedimentation in Lake Nasser, and a reduction in flooding" (IPoE, 2013:41). According to several studies (Tawfik, 2015:29; Abdelhaleem and Esam, 2015:462; Negm and Elsayed, 2015:1; Asegdew and Semu, 2015:583) and the report of IPoE, the negative impact of the project on Egypt is the reduction in power generation at High Aswan Dam which is very minimal and largely determined by the type and duration of reservoir filling strategy of GERD. GERD is thus a benefit sharing project. It will establish a new order based on principle of international water law if countries solved still unsolved issues cooperatively.

\section{Concluding Remarks}

This study attempted to investigate mechanisms of challenging hydro hegemony in the Eastern Nile basin. Accordingly, it argues that Egypt's incessant hydro hegemonic transboundary arrangement is now being contested and challenged through twin ways: war of position through CFA and war of movement through GERD. Both of them have played crucial roles not only in challenging but also in foreshadowing the end of the inequitable transboundary water management. Thus, GERD and CFA foreshadow a new emergent order capable of superseding the existing inequitable hegemonic order. Nevertheless, the anticipated new emergent order and playing filed is not yet realized rather it has faced several challenges due to Egypt's proactive move against the aforesaid mechanism. Therefore, this stud calls for:

$>$ First there is a need of the creation of Nile epistemic community which will play a great role for the realization of the anticipated new regime. Since Egyptian has developed deep sense of entitlement to the Nile River which is reinforced by mythology and institutionalized by their constitution and bilateral agreements, the unbiased view of knowledge based expert community will play a crucial role in decolonising hegemonic mind and in building the new order on strong rock. Thus, the creation of an expert knowledge based community the so-called Nile epistemic community would play a crucial role in ending the sense of monopolism, identity of inseparability, hegemonic constructed knowledge and discourse. By doing so, Nile epistemic community would play a role in consolidating the foundational base of the anticipated new emergent regime on the base of communal identity, evidence based scientific knowledge and discourse.

$>$ Second, the study implies for the need of domestic and foreign policy orientation on the part of Ethiopia. Domestically, there is an imperative to give due attention to State sustenance than regime sustenance. Being constitutionalism, internal cohesion and solidarity are the very path of survival for Ethiopia because the study shows that the most effective strategy being used and to be used more in the future by Egypt is destabilization. There is also a need of proactive foreign policy on the part of Ethiopia so as to realize the anticipated new equitable order. Falling to do so would mean letting the anticipated new equitable order to die from the outset because of the possible proactive strategies and tactics employed by Egypt.

$>$ There is also a need of 'decolonizing hegemonic mind' to show that 'Egypt is not the scared husband of Nile rather Nile has made a geographical and legal marriage with 11 countries'.

$>$ Finally, there is a need of 'historic non-hegemonic block' in order to bring consistent unified upstream position which will bring a pragmatic change.

\section{References}

Abadir Ibrahim (2011). The Nile Basin Cooperative Framework Agreement: The Beginning of The End of

\footnotetext{
${ }^{1}$ Interview with Zerihun Abebe
} 
Egyptian Hydro-Political Hegemony. Environmental law and policy Review, 18(2), Pp. 283-313.

Allan, John Anthony (2009). Nile Basin Asymmetries: A Closed Fresh Water Resource, Soil Water Potential, the Political Economy and Nile Transboundary Hydropolitics. In Henri J. Dumont (Ed.), The Nile Origin, Environments, Limnology and Human Use (Pp. 749-769) [Monograph]. Springer.

Al Rasheedy, Ahmad and Hamdy A. Hassan (2007). The Nile River and Egyptian Foreign Policy Interests. African Sociological Review, 11 (1), Pp.25-37.

Bayleyegn Tasew (1998). Myth and Reality: Minds of Ethiopian Poets on the Blue Nile. In Proceedings of the $V^{\text {th }}$ Nile 2002 Conference on Comprehensive Water Resources Development of the Nile Basin: Basis for Cooperation, 24-28 February 1997 (Pp. 361 - 369). Addis Ababa, Ethiopia: Ministry of Water Resources.

Berridge, G.R. (2010). Diplomacy: Theory and Practice ( $4^{\text {th }}$ Ed.). London: Palgrave Macmillan.

Buzan, Barry (1981). Negotiating by Consensus: Developments in Technique at the United Nations Conference on the Law of the Sea. The American Journal of International Law, 75(2), Pp.324-348.

Cascão, Ana Elisa and Mark Zeitoun (2010). Power, Hegemony and Critical Hydropolitics.

In Earle A., A. Jagerskog and J. Ojendal (Eds.), Transboundary Water Management: $\quad$ Principles and Practice (Pp. 27-42). London: Earthscan.

Cox, Robert W. (1993). Gramsci, Hegemony and International Relations: An Essay in Method. Millennium: Journal of International Studies, 12 (2), Pp. 162-175.

Cascão, Ana Elisa (2009). Changing Power Relations in the Nile River Basin: Unilateralism vs. Cooperation? Water Alternatives 2(2), Pp. 245 - 268.

Dereje Zeleke Mekonnen (2010b). From Tenuous Legal Arguments to Securitization and Benefit Sharing: hegemonic Obstinacy- The Stumbling Block against Resolution of the Nile Waters Question. Mizan Law Review, 4(2), Pp. 232-257.

Dereje Zeleke Mekonnen (2011) Between the Scylla of Water Security and Charybdis of Benefit Sharing: The Nile Basin Cooperative Framework Agreement - Failed or Just Teetering on the Brink? Goettingen Journal of International Law, 3(1), Pp.345-372.

Dejazmach Zewude G/Sellasie (2002). The Nile River questions in a new era of cooperation Among Riparian States. Key Notes Presented at VIII ${ }^{\text {th }}$ Nile-2002 conference proceedings, on Comprehensive water resources development of the Nile basin: Priorities for the New Century, 26-29 June 2000 (Pp. 516-527). Addis Ababa, Ethiopia: Ministry of Water Resources

ENTRO (20 June 2016). About Eastern Nile. Retrieved 20 April 2017 From http://entro.nilebasin.org/index.php/about-the-sub-basin/151-learn-about-eastern-nile

FDRE (1997). Baro-Akobo River Basin Integrated Development Master Plan Study Final Report. Vol. II.

FDRE (1998a). Abbay River Basin Integrated Development Master Plan Project Phase 3 Master Plan Main Report. Part I.

FDRE (1998b). Tekeze River Basin Integrated Development Master Plan Main Report. Vol. I.Goitom Gebrelue (2014). Ethiopia's Grand Renaissance Dam: Ending Africa's Oldest Geopolitical Rivalry? The Washington Quarterly, 37(2), Pp.25-37.

Kasimbazi, Emmanuel B (2011a). Developing a Cooperative Framework Agreement for a Transboundary River: Lessons from a Comparative Analysis of the Mekong And Nile Rivers Basins. US-China Law Review. 8, Pp. 724-757.

Kasimbazi, Emmanuel B. (2010). The Impact Of Colonial Agreements On The Regulation Of The Waters Of The River Nile. Water International, 35(6), Pp. 718-732.

Keohane, Robert O. (1984). After Hegemony: Cooperation And Discord in the World Political Economy. Princeton, Newjersey: Princeton University Press.

Lears, T.J. Jackson (1985). The Concept of Cultural Hegemony: Problems and Possibilities. The American Historical Review, 90(3), Pp.567-593.

Movsisyan, Suren (2008). Decision Making By Consensus in International Organizations as a Form of Negotiation. 21-St Century, 1 (3), Pp. 77-86.

NBI (2016). Nile Basin Water Resources Atlas. Kampala, Uganda: New Vision Printing and Publishing Company.

The Nile Basin Initiative Act, 2002. Retrieved 10 December 2016 Form http://extwprlegs1.fao.org/docs/pdf/uga80648.pdf

Oestigaard, T. and A. F. Gedef (2011). Gish Abay: the source of the Blue Nile. Water and Society, 153 (27-38).

Swain, Ashok (2011). Challenges for Water Sharing In the Nile Basin: Changing Geo-Politics and Changing Climate. Hydrological Sciences Journal, 56(4), Pp. 687-702.

Tawfik, Rawia (2016). The Grand Ethiopian Renaissance Dam: benefit-sharing project in the Eastern Nile? Water International. 41 (4), Pp. 574-592.

Tawfik, Rawia (2015). The Declaration of Principles on Ethiopia's Renaissance Dam: A Breakthrough or another Unfair Deal? The Current Column, German Development Institute. 
Tesfaye Tafesse (2011). Water conflict resolution and institution building in the Nile Basin. In Berouk Mesfin and Roba Sharamo (Eds.), Regional Security in the post-Cold War Horn of Africa (Pp.257-281) [Monograph]. Institute for Security Studies.

Warner, Jeroen and Neda Zawahri (2012). Hegemony and Asymmetry: Multiple- Chessboard Games on Transboundary Rivers. International Environment Agreements.

Wessels, Josepha Ivanka (2015). Challenging Hydro-Hegemony: Hydro-Politics and Local Resistance in the Golan Heights and the Palestinian Territories. International Journal of Environmental Studies, 72(4), Pp. 601-623

Warner, Jeroen and Mark Zeitoun (2006). Hydro-Hegemony - A Framework for Analysis Of Trans-Boundary Water Conflicts. Water Policy, 8, Pp. 435-460.

Yacob Arsano (2007). Ethiopia and the Nile: Dilemmas of National and Regional Hydropolitics. Doctoral Dissertation. Center for Security Studies, Swiss Federal Institute of Technology, Zurich University of Zurich.

Yacob Arsano (2000).The Nile Basin: Upstream Perspective of Cooperation in the New Millennium. In VIII ${ }^{\text {th }}$ Nile 2002 Conference proceedings on Comprehensive water resources Development of the Nile basin: Priorities for the New Century, 26-29 June 2000 (Pp. 610-616). Addis Ababa, Ethiopia: Ministry of Water Resources.

Yohannes, Okbazghi (2008). Water Resources and Inter-Riparian Relations in the Nile Basin: The Search for an Integrative Discourse. Albany: State University of New York Press.

Zeitoun, Mark (2008). Power and Water In The Middle East: The Hidden Politics Of The Palestinian-Israeli Water Conflict. London: I.B.Tauris \& Co Ltd.

Zerihun Abebe Yigzaw (18 May 2013). The Nile: Why multilateralism and no room for divide And rule? Retried 10 April 2017 from https://zenileabbay.wordpress.com/2013/05/18/the-nilewhy-multilateralism-and-noroom-for-divide-and-rule/

Zerihun Megersa Jima (23 October 2016). The Grand Ethiopian Renaissance Dam: A Game-Changer For Nile Hydro-Politics. Retrieved 10 April 2017 From https://www.africanglobe.net/africa/grand-ethiopianrenaissance-dam-game-changer-nile-hydro-politics/

Zeray Yihdego \& Alistair Rieu-Clarke (2016) An exploration of fairness in international law through the Blue Nile and GERD, Water International, 41:4, 528-549 